\title{
Transactions
}

\section{Copper(I) and nickel(II) complexes with $1: 1$ vs. $1: 2$ coordination of ferrocenyl hydrazone ligands: Do the geometry and composition of complexes affect DNA binding/cleavage, protein binding, antioxidant and cytotoxic activities?†}

\author{
Paramasivam Krishnamoorthy, ${ }^{a}$ Palanisamy Sathyadevi, ${ }^{a}$ Rachel R. Butorac, ${ }^{b}$ Alan H. Cowley, ${ }^{b}$ Nattamai \\ S. P. Bhuvanesh ${ }^{c}$ and Nallasamy Dharmaraj $*^{a}$
}

Received 13th October 2011, Accepted 12th December 2011

DOI: $10.1039 / \mathrm{c} 2 \mathrm{dt11938b}$

A new series of geometrically different complexes containing ferrocenyl hydrazone ligands were synthesised by reacting suitable precursor complex $\left[\mathrm{MCl}_{2}\left(\mathrm{PPh}_{3}\right)_{2}\right]$ with the ligands $\mathrm{HL}^{1}$ or $\mathrm{HL}^{2}$ (where $\mathrm{M}$ $=\mathrm{Cu}(\mathrm{II})$ or $\mathrm{Ni}(\mathrm{II}) ; \mathrm{HL}^{1}=\left[\mathrm{Cp}_{2} \mathrm{Fe}\left(\mathrm{CH}=\mathrm{N}-\mathrm{NH}-\mathrm{CO}-\mathrm{C}_{6} \mathrm{H}_{5}\right)\right](\mathbf{1})$ and $\mathrm{HL}^{2}=\left[\mathrm{Cp}_{2} \mathrm{Fe}(\mathrm{CH}=\mathrm{N}-\mathrm{NH}-\mathrm{CO}-\right.$ $\left.\left.\left.\mathrm{C}_{5} \mathrm{H}_{4} \mathrm{~N}\right)\right]\right)(2)$. The new complexes of the composition $\left[\mathrm{Cu}\left(\mathrm{L}^{1}\right)\left(\mathrm{PPh}_{3}\right)_{2}\right],(3)\left[\mathrm{Cu}\left(\mathrm{L}^{2}\right)\left(\mathrm{PPh}_{3}\right)_{2}\right](4),\left[\mathrm{Ni}\left(\mathrm{L}^{1}\right)_{2}\right]$ (5) and $\left[\mathrm{Ni}\left(\mathrm{L}^{2}\right)_{2}\right](\mathbf{6})$ were characterised by various spectral studies. Among them, complexes $\mathbf{3}$ and $\mathbf{5}$ characterised by single crystal X-ray diffraction showed a distorted tetrahedral structure for the former with 1:1 metal-ligand stoichiometry, but a distorted square planar geometry with $1: 2$ metal-ligand stoichiometry in the case of the latter. Systematic biological investigations like DNA binding, DNA cleavage, protein binding, free radical scavenging and cytotoxicity activities were carried out using all the synthesised compounds and the results obtained were explained on the basis of structure-activity relationships. The binding constant $\left(K_{\mathrm{b}}\right)$ values of the synthesised compounds are found to be in the order of magnitude $10^{3}-10^{5} \mathrm{M}^{-1}$ and also they exhibit significant cleavage of supercoiled (SC) pUC19 DNA in the presence of $\mathrm{H}_{2} \mathrm{O}_{2}$ as co-oxidant. The conformational changes of bovine serum albumin (BSA) upon binding with the above complexes were also studied. In addition, concentration dependent free radical scavenging potential of all the synthesised compounds (1-6) was also carried out under in vitro conditions. Assays on the cytotoxicity of the above complexes against HeLa and A431 tumor cells and NIH 3 T3 normal cells were also carried out.

\section{Introduction}

Schiff bases together with various metals have been extensively used as building blocks to produce a great variety of topologies. Among them, hydrazones have attracted special attention from

${ }^{a}$ Department of Chemistry, Bharathiar University, Coimbatore, 641046 , India.E-mail: dharmaraj@buc.edu.in; Fax: +91 422 2422387; Tel: +914222428316

${ }^{b}$ Department of Chemistry and Biochemistry, University of Texas at Austin, Austin, Texas 78712, USA

${ }^{c}$ Department of Chemistry, Texas A\&M University, College Station, TX 77843, USA

$\dagger$ Electronic supplementary information (ESI) available: Crystal packing diagram of the unit cell of complexes 3 and $\mathbf{5}$ (Fig. S1 and S2), Electronic absorption spectra of binding of ligands $\mathbf{1}$ and $\mathbf{2}$ with DNA (Fig. S3), Electronic absorption spectra of binding of complexes 3, 4 and 5 with DNA (Fig. S4 and S5), Circular dichroism spectra of DNA and ligands 1 and 2 (Fig. S6), Circular dichroism spectra of DNA and complexes 3, 4 (Fig. S7), Emission spectra of binding of complexes 3, 4 and 5 with BSA (Fig. S8 and S9), Synchronous spectra $(\Delta \lambda=15$ and $60 \mathrm{~nm}$ ) of binding of complexes $\mathbf{3}, \mathbf{4}$ and $\mathbf{5}$ with BSA (Fig. S10, S11 and S12). CCDC reference numbers 796259 and 822888 for complexes 3 and 5. For ESI and crystallographic data in CIF or other electronic format see DOI: $10.1039 / \mathrm{c} 2 \mathrm{dt} 11938 \mathrm{~b}$ researchers due to their well known chelating capability and structural flexibility that can provide rigidity to the skeletal framework of the prepared metal complexes. ${ }^{1-5}$ Hydrazones and analogous compounds play an important role in improving the selectivity and toxicity profile of certain antitumor agents by forming drug carrier systems employing suitable carrier proteins. ${ }^{6}$ The real impetus towards developing the coordination chemistry of these hydrazones has been provided by the remarkable biological activities exhibited by them that are related to their metal complexing ability.

Large numbers of ferrocene-containing metal chelates are in fact multinuclear molecules possessing features of both organometallic and coordination chemistry. ${ }^{7,8}$ Aroyl hydrazones attached to a ferrocenyl molecule have been studied in detail owing to their plentiful coordination chemistry and antibiotic activity as well as the fact that azomethine ligands are models for metal-ligand binding sites in several enzymes. ${ }^{9-15}$ Complexes of aroyl hydrazones containing both heterocycles and the ferrocenyl group within the same molecule have been scarcely investigated so far and therefore we felt that it appropriate to undertake a systematic study involving such a novel system and to understand their behaviour towards a series of biological experiments. 
Further, most of the first row transition metals either alone or in their complex form are biologically essential with a number of known bioactivities. Among them, copper and nickel are especially notable as they are involved in many biological processes. $^{16-25}$ The interactions between bio-macromolecules and drugs have attracted special interest among both chemistry and biology researchers during the past few decades. ${ }^{26-28}$ Since DNA is one of the main molecular targets in the design of anticancer compounds, interaction between nucleic acids and other molecules is a fundamental issue in life science that relates the replication, transcription, mutation of genes and related variations of species in character, origin of some diseases and mechanism of interaction of some DNA-targeted drugs. ${ }^{29-32}$ Another biomolecule, serum albumin (BSA) is a major soluble protein constituent of the circulatory system and has many physiological functions, e.g. it serves as a depot protein for many exogenous compounds. $^{33,34}$ Significant interaction of any drug with a protein may result in the formation of a stable protein-drug complex, which has an important effect on the distribution, metabolism and the efficacy of drugs, etc. Copper and nickel being bio-essential elements, it is considered that their complexes can find more applications in various biological processes.

Based on the above facts, we undertook this study to prepare some new hydrazone complexes of copper and nickel from the reactions of $\left[\mathrm{MCl}_{2}\left(\mathrm{PPh}_{3}\right)_{2}\right]$ with $\mathrm{HL}^{n}$ (where $\mathrm{M}=\mathrm{Cu}$ (II) or $\mathrm{Ni}$ (II); $n=1$ or 2) in 1:1 metal-to-ligand stoichiometry. Further, a systematic investigation on the effects of the free ligands and the corresponding newly synthesised copper/nickel hydrazone complexes with respect to DNA binding, DNA cleavage, protein interaction, in vitro free radical scavenging and cytotoxic activities has also been carried out.

\section{Experimental}

\section{Materials and physical measurements}

Reagent grade chemicals were used without further purification in all the synthetic work. Solvents were purified by standard methods. The compounds $\mathrm{CuCl}_{2} \cdot 2 \mathrm{H}_{2} \mathrm{O}, \mathrm{NiCl}_{2} \cdot 6 \mathrm{H}_{2} \mathrm{O}$, triphenylphosphine, benzhydrazide and isonicotinic acid hydrazide purchased from Sigma-Aldrich Chemie or Alfa Aesar were used as received. Calf-thymus DNA (CT-DNA) and bovine serum albumin (BSA) were purchased from Himedia Company. The plasmid supercoiled (SC) pUC19 DNA was purchased from Bangalore GeNei, Bangalore, India. The human cervical cancer cell line (HeLa), human skin cancer cell line (A431) and mouse embryonic fibroblasts (NIH 3T3) was obtained from the National Centre for Cell Science (NCCS), Pune, India. All other chemicals and reagents used for the biological studies were of high quality and procured commercially from reputable suppliers.

Microanalyses $(\% \mathrm{C}, \mathrm{H} \& \mathrm{~N})$ were performed on a Vario EL III CHNS analyzer. IR spectra of the samples were recorded as $\mathrm{KBr}$ pellets on a Nicolet Avatar instrument in the frequency range of $400-4000 \mathrm{~cm}^{-1}$. ${ }^{1} \mathrm{H}$ NMR spectra of ligands and metal complexes were recorded on a Bruker AMX 500 spectrometer operating at $500 \mathrm{MHz}$ using $\mathrm{CDCl}_{3}$ as solvent and tetramethylsilane as an internal standard. The electronspray ionization mass (ESI-MS) spectra of the complexes and ligands in methanol were recorded on a THERMO Finnigan LCQ Advantage max ion trap mass spectrometer. The electronic absorption and emission spectra were recorded in DMSO-buffer (1:99) solution on a Jasco V-630 spectrophotometer and Jasco FP 6600 spectrofluorometer respectively at room temperature. The circular dichroism experiments were carried out using a Jasco J-810 spectropolarimeter at room temperature.

\section{X-Ray crystallography}

For each compound, a crystal of suitable quality was removed from the vial, covered with mineral oil and mounted on a nylon thread loop. X-Ray diffraction data of the complexes $\mathbf{3}$ and $\mathbf{3 a}$ were obtained using a Rigaku AFC-12 Saturn 724+ CCD diffractometer equipped with a graphite-monochromated Mo-K $\alpha$ radiation source $(\lambda=0.7107 \AA)$ whereas complex 5 was collected on a BRUKER GADDS X-ray (three-circle) diffractometer equipped with a $\mathrm{Cu}-\mathrm{K} \alpha$ radiation source $(\lambda=1.5418 \AA)$. Corrections were applied for Lorentz and polarization effects for each of the compounds. Each structure was solved by direct methods and refined by full-matrix least-squares cycles on $F^{2}$ using the Siemens SHELXTL PLUS 5.0 (PC) software package $^{35,36}$ and PLATON. ${ }^{37}$ All non-hydrogen atoms were refined anisotropically and hydrogen atoms were placed in fixed, calculated positions using a riding model.

\section{Synthesis of starting metal complexes}

The requisite precursor metal complexes $\left[\mathrm{CuCl}_{2}\left(\mathrm{PPh}_{3}\right)_{2}\right]$ and $\left[\mathrm{NiCl}_{2}\left(\mathrm{PPh}_{3}\right)_{2}\right]$ were prepared according to the literature methods. ${ }^{38,39}$

\section{Synthesis of hydrazone ligands}

Synthesis of formyl ferrocene-2-benzoyl hydrazone $\left(\mathrm{HL}^{\mathbf{1}}\right)(\mathbf{1})$ and formyl ferrocene 2-isonicotinyl hydrazone $\left(\mathrm{HL}^{2}\right)$ (2). Ligands 1 and $\mathbf{2}$ were prepared by refluxing equimolar solutions of ferrocene-2-carbaldehyde $(0.214 \mathrm{~g} ; 1 \mathrm{mM})$ and benzhydrazide $(0.136 \mathrm{~g} ; 1 \mathrm{mM})$ or isonicotinic acid hydrazide $(0.137 \mathrm{~g}$; $1 \mathrm{mM}$ ) respectively in $50 \mathrm{~mL}$ of ethanol for $8 \mathrm{~h}$ as summarised in Scheme 1. The reaction mixture was cooled to room temperature and the product formed was filtered, washed several times with water, and then recrystallized from ethanol to afford the desired product in pure form.

$\mathrm{HL}^{1}$ (1): Yield: $259 \mathrm{mg}$ (78\%), Anal. Found (\%) for $\mathrm{C}_{18} \mathrm{H}_{16} \mathrm{~N}_{2} \mathrm{OFe}(\mathrm{Mol} . \mathrm{wt}=332.18$ ): C, 64.78\%; H, 5.12\%; N, $8.75 \%$. Calculated (\%) C, 65.09\%; H, 4.86\%; N, 8.43\%. ESI-MS (MeOH): Found $m / z=333(\mathrm{M}+\mathrm{H})($ calculated $m / z=$ 332 for $\left.\mathrm{M}^{+}\right)$. Selected IR bands $\left(v\right.$ in $\left.\mathrm{cm}^{-1}\right)$ : $3224(-\mathrm{NH}) ; 1648$ $(=\mathrm{C}=\mathrm{O}) ; 1605 \quad(=\mathrm{C}=\mathrm{N}-) ; 1044 \quad(=\mathrm{N}-\mathrm{N}-) . \quad{ }^{1} \mathrm{H} \quad \mathrm{NMR}$ $\left(500 \mathrm{MHz}, \mathrm{CDCl}_{3}\right): \delta(\mathrm{ppm}): 9.04(\mathrm{~s}, 1 \mathrm{H},-\mathrm{NH}) ; 8.31$ (s, $1 \mathrm{H}$, $-\mathrm{OH}$ enolic form); $7.87(\mathrm{~s}, 1 \mathrm{H},-\mathrm{HC}=\mathrm{N}-) ; 7.57-7.48(1 \mathrm{~d} \& 1 \mathrm{t}$, 5H, Ar-H); 4.73-4.24 (3 s, 9H, cp-H).

$\mathrm{HL}^{2}$ (2): Yield: $239 \mathrm{mg}$ (72\%), Anal. Found (\%) for $\mathrm{C}_{17} \mathrm{H}_{15} \mathrm{~N}_{3} \mathrm{OFe}$ (Mol. wt = 333.17): C, 60.99\%; H, 4.32\%; N, $12.89 \%$. Calculated (\%) C, 61.29\%; H, 4.54\%; N, 12.61\%. ESI-MS (MeOH): Found $m / z=334(\mathrm{M}+\mathrm{H})($ calculated $m / z=$ 333 for $\left.\mathrm{M}^{+}\right)$. Selected IR bands $\left(v\right.$ in $\left.\mathrm{cm}^{-1}\right)$ : $3235(-\mathrm{NH}) ; 1636$ 


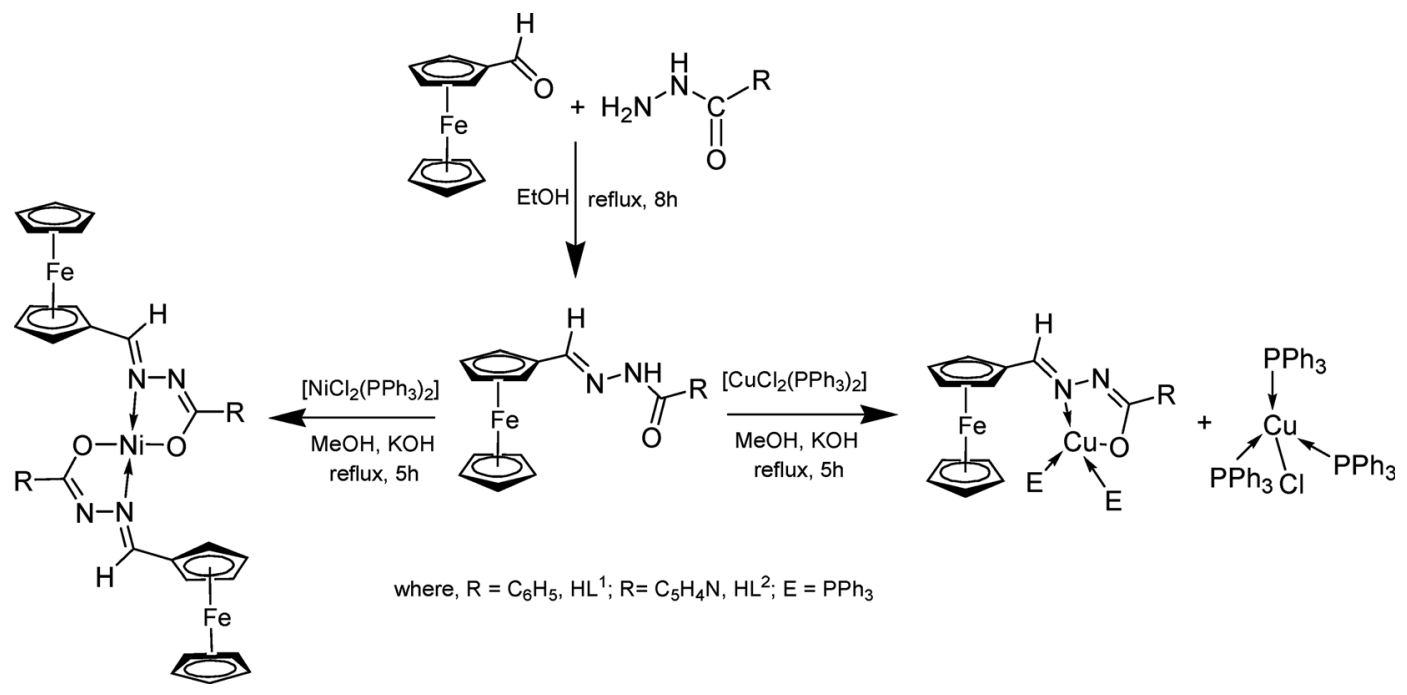

Scheme 1

$(>\mathrm{C}=\mathrm{O}) ; 1592 \quad(=\mathrm{C}=\mathrm{N}-) ; 1035 \quad(=\mathrm{N}-\mathrm{N}=) .{ }^{1} \mathrm{H} \quad \mathrm{NMR}$ $\left(500 \mathrm{MHz}, \mathrm{CDCl}_{3}\right): \delta(\mathrm{ppm}): 9.12(\mathrm{~s}, 1 \mathrm{H},-\mathrm{NH}) ; 8.54(\mathrm{~s}, 1 \mathrm{H}$, $-\mathrm{OH}$ enolic form); $7.88(\mathrm{~s}, 1 \mathrm{H},-\mathrm{HC}=\mathrm{N}-)$; 7.31-7.16 (2d, $4 \mathrm{H}$, $\mathrm{Ar}-\mathrm{H}) ;$ 4.56-3.81 (3 s, 9H, cp-H).

\section{Synthesis of metal hydrazone complexes 3-6}

Complexes $\left[\mathrm{Cu}\left(\mathrm{L}^{1}\right)\left(\mathrm{PPh}_{3}\right)_{2}\right]$ (3) and $\left[\mathrm{CuCl}\left(\mathrm{PPh}_{3}\right)_{3}\right]$ (3a) were prepared by refluxing equimolar quantities of $\left[\mathrm{CuCl}_{2}\left(\mathrm{PPh}_{3}\right)_{2}\right]$ $(0.658 \mathrm{~g} ; 1 \mathrm{mM})$ and the hydrazone ligand $\left(\mathrm{HL}^{1}\right)(\mathbf{1})(0.332 \mathrm{~g}$; $1 \mathrm{mM}$ ) in $40 \mathrm{~mL}$ of methanol (Scheme 1). After a few minutes of mixing of the above reactants, 2 or 3 drops of methanolic $\mathrm{KOH}$ was added to the reaction mixture and continuously refluxed for $5 \mathrm{~h}$. It is then cooled to room temperature, and the resulting product was filtered off, washed with methanol and dried under vacuum. Purity of the above product checked by TLC revealed the presence of two distinct spots, i.e., complexes $\mathbf{3}$ and 3a that were subsequently separated by column chromatography using a mixture of petroleum ether and ethyl acetate as an eluent. Slow evaporation of both $\mathbf{3}$ and $\mathbf{3 a}$ in $\mathrm{MeOH} / \mathrm{CHCl}_{3}$ mixture afforded single crystals of respective complexes suitable for X-ray diffraction studies. The data corresponding to complex 3 were as follows: Yield: (395 mg) 43\%. mp: $270{ }^{\circ} \mathrm{C}$. Anal. Found (\%) for $\mathrm{C}_{54} \mathrm{H}_{45} \mathrm{~N}_{2} \mathrm{OFeP}_{2} \mathrm{Cu}$ (Mol. wt $\left.=919.29\right)$ : $\mathrm{C}$, $70.08 \%$; H, 4.12\%; N, 2. 83\%. Calculated (\%) for C, $70.55 \%$; $\mathrm{H}, 4.93 \%$; N, 3.05\%. ESI-MS (MeOH): Found $m / z=920$ $(\mathrm{M}+\mathrm{H})\left(\right.$ calculated $m / z=919$ for $\left.\mathrm{M}^{+}\right)$. Selected IR bands $(v$ in $\left.\mathrm{cm}^{-1}\right)$ : $1584 \& 1505(>\mathrm{C}=\mathrm{N}-\mathrm{N}=\mathrm{C}<)$; 1368 (phenolic $\left.-\mathrm{C}-\mathrm{O}\right)$; 1314 (enolic $-\mathrm{C}-\mathrm{O}) ; 1093(=\mathrm{N}-\mathrm{N}=) .{ }^{1} \mathrm{H}$ NMR $(500 \mathrm{MHz}$, $\left.\mathrm{CDCl}_{3}\right): \delta(\mathrm{ppm}): 8.50(\mathrm{~s}, 1 \mathrm{H},-\mathrm{HC}=\mathrm{N}-) ; 7.68-7.26(1 \mathrm{~m}, 35 \mathrm{H}$, $\mathrm{Ar}-\mathrm{H}) ; 4.72-3.88$ (3 s, 9H, cp-H).

Complexes 4 and $\mathbf{4 a}$ were prepared by a procedure similar to that described above using $\left[\mathrm{CuCl}_{2}\left(\mathrm{PPh}_{3}\right)_{2}\right](0.658 \mathrm{~g} ; 1 \mathrm{mM})$ and ligand $\mathrm{HL}^{2}$ (2) (0.333 g; $\left.1 \mathrm{mM}\right)$ (Scheme 1). Isolation of the crystals suitable for single crystal XRD studies were unsuccessful in the case of complex 4 whereas complex $\mathbf{4 a}$ afforded white crystals on crystallization and were identified to be $[\mathrm{CuCl}$ $\left.\left(\mathrm{PPh}_{3}\right)_{3}\right]$ as obtained in the previous reaction as 3a. The data corresponding to complex 4 were as follows: Yield: (377 mg) 41\%. mp: $285{ }^{\circ} \mathrm{C}$ Anal. Found (\%) for $\mathrm{C}_{53} \mathrm{H}_{44} \mathrm{~N}_{3} \mathrm{OFeP}_{2} \mathrm{Cu}(\mathrm{Mol}$. wt $=920.28):$ C, 59.98\%; H, 4.12\%; N, 4.03\%. Calculated $(\%)$ for C, $69.17 \%$; H, 4.82\%; N, 4.57\%. ESI-MS (MeOH): Found $m / z=921(\mathrm{M}+\mathrm{H})\left(\right.$ calculated $m / z=920$ for $\left.\mathrm{M}^{+}\right)$. Selected IR bands $\left(v\right.$ in $\left.\mathrm{cm}^{-1}\right)$ : $1583 \& 1509(>\mathrm{C}=\mathrm{N}-\mathrm{N}=\mathrm{C}<)$; 1362 (phenolic $-\mathrm{C}-\mathrm{O}) ; 1314$ (enolic $-\mathrm{C}-\mathrm{O}) ; 1092(=\mathrm{N}-\mathrm{N}=) .{ }^{1} \mathrm{H}$ NMR $\left(500 \mathrm{MHz}, \mathrm{CDCl}_{3}\right): \delta(\mathrm{ppm}): 8.56(\mathrm{~s}, \quad 1 \mathrm{H}, \quad-\mathrm{HC}=\mathrm{N}-)$; 7.40-7.22 (m, 34H, Ar-H); 4.70-3.82 (3 s, 9H, cp-H).

Complex 5 was prepared by a procedure similar to that described for the above complexes $\mathbf{3}$ or $\mathbf{4}$ by utilising $\left[\mathrm{NiCl}_{2}\left(\mathrm{PPh}_{3}\right)_{2}\right](0.653 \mathrm{~g} ; 1 \mathrm{mM})$ and the ligand 1 (0.332 g; $1 \mathrm{mM}$ ) as reactants (Scheme 1). Purity of the product 5 formed in this reaction checked by TLC confirmed it to be a single spot. The slow evaporation of complex 5 in $\mathrm{MeOH} / \mathrm{CHCl}_{3}$ solution afforded red crystals suitable for X-ray diffraction studies. Yield: (346 mg) 48\%. mp: $>300{ }^{\circ} \mathrm{C}$. Anal. Found (\%) for $\mathrm{C}_{36} \mathrm{H}_{30} \mathrm{~N}_{4} \mathrm{O}_{2}$ $\mathrm{Fe}_{2} \mathrm{Ni}(\mathrm{Mol} . \mathrm{wt}=721.028): \mathrm{C}, 59.02 \% ; \mathrm{H}, 3.97 \% ; \mathrm{N}, 7.12 \%$. Calculated (\%) for C, 59.96\%; H, 4.19\%; N, 7.77\%. ESI-MS $(\mathrm{MeOH})$ : Found $m / z=722(\mathrm{M}+\mathrm{H})$ (calculated $m / z=721$ for $\left.\mathrm{M}^{+}\right)$. Selected IR bands $\left(v\right.$ in $\left.\mathrm{cm}^{-1}\right): 1588 \& 1518(=\mathrm{C}=\mathrm{N}-$ $\mathrm{N}=\mathrm{C}<$ ); 1357 (phenolic $-\mathrm{C}-\mathrm{O}$ ); 1305 (enolic $-\mathrm{C}-\mathrm{O}$ ); 1066 $(=\mathrm{N}-\mathrm{N}=) .{ }^{1} \mathrm{H}$ NMR $\left(500 \mathrm{MHz}, \mathrm{CDCl}_{3}\right): \delta(\mathrm{ppm}): 8.01(\mathrm{~s}, 2 \mathrm{H}$, $-\mathrm{HC}=\mathrm{N}-)$; 7.46-7.16 (1d \&1t, $10 \mathrm{H}, \mathrm{Ar}-\mathrm{H}) ; 5.28-4.33$ (3 s, $18 \mathrm{H}, \mathrm{cp}-\mathrm{H})$.

Complex 6 was prepared by a procedure similar to that described for complex 5 by utilizing $\left[\mathrm{NiCl}_{2}\left(\mathrm{PPh}_{3}\right)_{2}\right](0.653 \mathrm{~g}$; $1 \mathrm{mM}$ ) and ligand $2(0.333 \mathrm{~g} ; 1 \mathrm{mM})$ (Scheme 1$)$. Attempts to isolate crystals suitable for single crystal XRD were unsuccessful. Yield: (318 mg) 44\%. mp: $>300{ }^{\circ} \mathrm{C}$. Anal. Found $(\%)$ for $\mathrm{C}_{34} \mathrm{H}_{28} \mathrm{~N}_{6} \mathrm{O}_{2} \mathrm{Fe}_{2} \mathrm{Ni}$ (Mol. wt = 723.002): C, 55.98\%; H, 3.11\%; $\mathrm{N}, 11.09 \%$. Calculated $(\%)$ for $\mathrm{C}, 56.48 \%$;, $3.90 \%$; , $11.62 \%$. ESI-MS $(\mathrm{MeOH})$ : Found $m / z=724(\mathrm{M}+\mathrm{H})($ calculated $m / z=723$ for $\left.\mathrm{M}^{+}\right)$. Selected IR bands $\left(v\right.$ in $\left.\mathrm{cm}^{-1}\right): 1599 \& 1519$ $(>\mathrm{C}=\mathrm{N}-\mathrm{N}=\mathrm{C}<)$; 1372 (phenolic $-\mathrm{C}-\mathrm{O}) ; 1305$ (enolic $-\mathrm{C}-\mathrm{O})$; $1088(=\mathrm{N}-\mathrm{N}=) .{ }^{1} \mathrm{H}$ NMR $\left(500 \mathrm{MHz}, \mathrm{CDCl}_{3}\right): \delta(\mathrm{ppm}): 8.04$ $(\mathrm{s}, 2 \mathrm{H},-\mathrm{HC}=\mathrm{N}-) ; 7.49-7.18(2 \mathrm{~d}, 8 \mathrm{H}, \mathrm{Ar}-\mathrm{H}) ; 5.20-4.35(3 \mathrm{~s}$, $18 \mathrm{H}, \mathrm{cp}-\mathrm{H})$. 


\section{DNA binding experiments}

Electronic absorption titration. Electronic absorption titrations were performed with a fixed concentration of ligands $\mathbf{1}$ and 2 and their metal complexes 3-6 $(25 \mu \mathrm{M})$ but by varying nucleotide concentration from 0 to $25 \mu \mathrm{M}$. The absorption band of the compounds 1-6 that have undergone significant shift due to the addition of CT DNA was chosen to monitor as an indication of binding between them. From the absorption titration data, the intrinsic binding constant $\left(K_{\mathrm{b}}\right)$ of the test compounds with $\mathrm{CT}$ DNA was determined using the equation, ${ }^{40}[\mathrm{DNA}] /\left[\varepsilon_{\mathrm{a}}-\varepsilon_{\mathrm{f}}\right]=$ [DNA] $/\left[\varepsilon_{\mathrm{b}}-\varepsilon_{\mathrm{f}}\right]+1 / K_{\mathrm{b}}\left[\varepsilon_{\mathrm{b}}-\varepsilon_{\mathrm{f}}\right]$, where [DNA] is the concentration of DNA, $\varepsilon_{\mathrm{a}}, \varepsilon_{\mathrm{f}}$ and $\varepsilon_{\mathrm{b}}$ are the apparent extinction coefficient, the extinction coefficient for free test compounds and the extinction coefficient for the test compound in the fully bound form respectively. A plot of [DNA] $v s$. [DNA] $/\left(\varepsilon_{\mathrm{a}}-\varepsilon_{\mathrm{f}}\right)$ gives the intrinsic binding constant $K_{\mathrm{b}}$ as the ratio of slope to the intercept.

Circular dichroism study. CD spectroscopic technique is useful in monitoring the conformational changes induced by the interaction of drugs as well as destabilization of the DNA helix. The B-form conformation of DNA showed two consecutive CD bands in the UV region, a positive band at $275 \mathrm{~nm}$ due to base stacking and a negative band at $246 \mathrm{~nm}$ due to polynucleotide helicity. The conformational changes upon the addition of test compounds 1-6 was studied by keeping the concentration of DNA constant at $200 \mu \mathrm{M}$ and varying the test samples 1-6 with a concentration of $20 \mu \mathrm{M}$ in Tris- $\mathrm{HCl}$ buffer. The spectrum of control DNA and with increasing amounts of the test compound was monitored from 200 to $350 \mathrm{~nm}$. It is known that the changes in ellipticity are directly related to the conformational changes observed in circular dichroism. The changes in CD signals of DNA observed on intercalation with drugs may often be assigned to the corresponding changes in the DNA structure. ${ }^{41}$ Thus, simple groove binding and electrostatic interaction of small molecules show less or no perturbation on the base-stacking and helicity bands, while intercalation enhances the intensities of both the bands stabilizing the right-handed B conformation of DNA as observed for the classical intercalator methylene blue. $^{42}$

\section{DNA cleavage experiments}

The extent of DNA cleavage induced by the test compounds was monitored by agarose gel electrophoresis. A solution containing $25 \mu \mathrm{L}$ of pUC19 DNA $(1 \mu \mathrm{g}), \mathrm{HCl}(50 \mathrm{mM}, \mathrm{pH} 7.5), \mathrm{NaCl}$ $(50 \mathrm{mM})$, the metal complex $(35 \mu \mathrm{M})$ and $\mathrm{H}_{2} \mathrm{O}_{2}(60 \mu \mathrm{M})$ was incubated at $37{ }^{\circ} \mathrm{C}$ for $1 \mathrm{~h}$. Subsequently, $4 \mu \mathrm{L}$ of $6 \mathrm{X}$ DNA loading buffer containing $0.25 \%$ bromophenol blue, $0.25 \%$ xylene cyanol and $60 \%$ glycerol was added to the test solution and then mixed with $1 \%$ agarose gel containing $1.0 \mu \mathrm{g} \mathrm{mL}^{-1}$ of ethidium bromide. Electrophoresis was performed at $5 \mathrm{~V} \mathrm{~cm}^{-1}$ for $2 \mathrm{~h}$ in a TBE buffer and the bands were visualized under UV light and photographed. The cleavage efficiencies were measured using the BIORAD Gel Documentation System. The intensity of each band relative to that of the plasmid supercoiled form was multiplied by 1.43 to take account of the reduced affinity for ethidium bromide. ${ }^{43}$

\section{Protein binding studies}

Binding of metal hydrazone complexes with bovine serum albumin (BSA) was studied from the fluorescence spectra recorded with excitation at $280 \mathrm{~nm}$ and corresponding emission at $345 \mathrm{~nm}$ assignable to that of bovine serum albumin (BSA). Sample solutions were carefully degassed using pure nitrogen gas for $15 \mathrm{~min}$ by using quartz cells $(4 \times 1 \times 1 \mathrm{~cm})$ with high vacuum Teflon stopcocks. Stock solution of BSA was prepared in $50 \mathrm{mM}$ phosphate buffer $(\mathrm{pH}=7.2)$ and stored in the dark at $4{ }^{\circ} \mathrm{C}$ for further use. Concentrated stock solutions of the ligands and its copper complexes were prepared by dissolving them in DMSO: phosphate buffer (1:99) and diluted suitably with phosphate buffer to the required concentrations. $2.5 \mathrm{ml}$ of BSA solution $(\mu \mathrm{M})$ was titrated by successive additions of a $25 \mu \mathrm{l}$ stock solution of metal hydrazone complexes $\left(10^{-4} \mathrm{M}\right)$. Synchronous fluorescence spectra were also recorded using the same concentration of BSA and complexes as mentioned above.

\section{Antioxidant activity}

The DPPH, OH and NO radical scavenging activities of the free hydrazone ligands and corresponding metal complexes were determined by the methods described by Blois, Nash and Green et al., respectively. ${ }^{4-46}$ For each of the above assay, tests were run in triplicate by varying the concentration of the ligands $\mathbf{1}$ and 2 and its corresponding complexes 3-6 ranging from $10-50 \mu \mathrm{M}$. The percentage activity was calculated by using the formula, $\%$ activity $=\left[\left(A_{0}-A_{\mathrm{C}}\right) / A_{0}\right] \times 100$, where $A_{0}$ and $A_{\mathrm{C}}$ represent the absorbance in the absence and presence of the test compounds, respectively. The $50 \%$ activities $\left(\mathrm{IC}_{50}\right)$ were calculated from the results of percentage activity.

\section{Cytotoxicity studies}

The in vitro cytotoxicity assay $\left(\mathrm{IC}_{50}\right)$ was performed on the human cervical cancer cell line (HeLa), human skin cancer cell line (A431) and the mouse embryonic cell line (NIH 3T3). The HeLa tumor cell lines used in this work were grown in Eagles Minimum Essential Medium containing 10\% fetal bovine serum (FBS) and the NIH $3 \mathrm{~T} 3$ fibroblasts were grown in Dulbeccos Modified Eagles Medium (DMEM) containing 10\% FBS. For the screening experiments, the cells were seeded into 96-well plates in $100 \mathrm{ml}$ of the respective medium containing $10 \% \mathrm{FBS}$, at a plating density of 10,000 cells well ${ }^{-1}$. The cells were incubated at $37{ }^{\circ} \mathrm{C}$ in $5 \% \mathrm{CO}_{2}$ and $95 \%$ air at a relative humidity of $100 \%$ for $24 \mathrm{~h}$ prior to the addition of the complexes. The complexes were solubilized in dimethylsulfoxide and diluted in the respective serum free medium. After $24 \mathrm{~h}, 100 \mathrm{ml}$ of the medium containing the test compounds with various concentrations (e.g. 12.5, 25, 50, 100, 200 and $400 \mu \mathrm{M})$ was added and incubated at $37{ }^{\circ} \mathrm{C}$ in an atmosphere of $5 \% \mathrm{CO}_{2}$ and $95 \%$ air with $100 \%$ relative humidity for $48 \mathrm{~h}$. All measurements were made in triplicate and the medium containing no test complexes served as the control. After $48 \mathrm{~h}, 15 \mathrm{~mL}$ of MTT (5 mg mL $\left.{ }^{-1}\right)$ in phosphate buffered saline (PBS) was added to each well and incubated at $37{ }^{\circ} \mathrm{C}$ for $4 \mathrm{~h}$. The medium with MTT was then flicked off and the formazan crystals that had formed were solubilized in $100 \mathrm{~mL}$ of DMSO and the absorbance at $570 \mathrm{~nm}$ was 


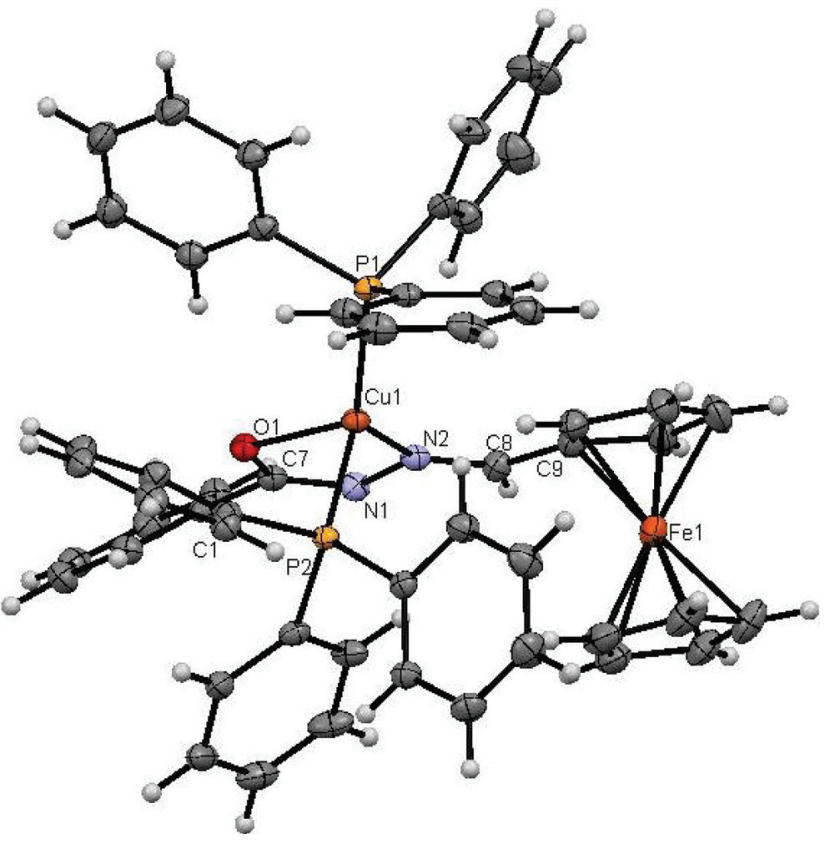

Fig. 1 The molecular structure of complex 3, with displacement ellipsoids drawn at $50 \%$ probability level.

measured using a micro plate reader. The $\%$ cell inhibition was determined using the following formula,

$\%$ Cell inhibition $=100-\mathrm{Abs}_{(\text {sample })} / \mathrm{Abs}_{(\text {control })} \times 100$.

The $\mathrm{IC}_{50}$ values were calculated from the graph plotted between $\%$ cell inhibition and concentration.

\section{Results and discussion}

\section{Characterisation of metal hydrazone complexes}

The analytical data of the ligands and their corresponding complexes summarized in the experimental section agreed well with the theoretical values within the limit of experimental error and confirmed the formulae $\left[\mathrm{Cu}\left(\mathrm{L}^{n}\right)\left(\mathrm{PPh}_{3}\right)_{2}\right]$ or $\left[\mathrm{Ni}\left(\mathrm{L}^{n}\right)_{2}\right](n=1$ or 2) proposed for the new complexes. All these complexes are insoluble in water but soluble in most of the common organic solvents.

\section{Single crystal X-ray studies}

\section{Structural description}

Complex 3. An ORTEP diagram of complex 3 is displayed in Fig. 1. The crystallographic data, along with a selection of bond lengths and bond angles, are presented in Tables 1 and 2, respectively. X-Ray results of complex 3 revealed that the crystals are comprised of monoclinic unit cells in the space group $P 2{ }_{1} / c$ with $Z=4$. The formula of the complex in the crystalline form is $\mathrm{C}_{54} \mathrm{H}_{45} \mathrm{CuFeN}_{2} \mathrm{OP}_{2}$. The central copper(I) ion adopts a distorted tetrahedral coordination sphere comprising an imine nitrogen (N2), an enolate oxygen (O1) of the hydrazone ligand and two phosphorus atoms of the triphenylphosphine of the
Table 1 Crystal and structure refinement data

\begin{tabular}{|c|c|c|}
\hline Description & Complex 3 & Complex 5 \\
\hline Formula & $\mathrm{C}_{54} \mathrm{H}_{45} \mathrm{CuFeN}_{2} \mathrm{OP}_{2}$ & $\mathrm{C}_{37} \mathrm{H}_{31} \mathrm{C}_{13} \mathrm{Fe}_{2} \mathrm{~N}_{4} \mathrm{NiO}_{2}$ \\
\hline Formula weight & 919.25 & 840.42 \\
\hline$T / \mathrm{K}$ & $100(2)$ & $110(2)$ \\
\hline$\lambda / \AA$ & 0.71075 & 1.54178 \\
\hline Crystal system & Monoclinic & Monoclinic \\
\hline Space group & $P 2_{1} / c$ & $P 2_{1} / n$ \\
\hline \multicolumn{2}{|l|}{ Cell dimensions } & $16.2656(8)$ \\
\hline$b / \AA$ & $17.8387(9)$ & $12.9068(6)$ \\
\hline$c / \AA$ & $20.7620(8)$ & $16.8967(8)$ \\
\hline$\alpha\left(^{\circ}\right)$ & 90 & 90 \\
\hline$\beta\left({ }^{\circ}\right)$ & $119.129(2)$ & $107.378(3)$ \\
\hline$\gamma\left({ }^{\circ}\right)$ & 90 & 90 \\
\hline$Z$ & 4 & 4 \\
\hline \multirow[t]{3}{*}{$h k l$ limits } & $-17 \leqq h \leqq 17$ & $-18 \leqq h \leqq 18$ \\
\hline & $-23 \leqq k \leqq 23$ & $-13 \leqq k \leqq 14$ \\
\hline & 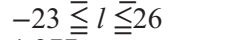 & $-18 \leqq l \leqq 18$ \\
\hline$D_{\text {calcd }}\left(\mathrm{Mg} \mathrm{m}^{-3}\right)$ & $1.37 \overline{7}-$ & $1.649-$ \\
\hline$F(000)$ & 1904 & 1712 \\
\hline Crystal size $\left(\mathrm{mm}^{3}\right)$ & $0.36 \times 0.24 \times 0.15$ & $0.40 \times 0.32 \times 0.06$ \\
\hline Independent & $10114[R($ int $)=$ & $5006[R($ int $)=0.0805]$ \\
\hline reflections & $0.0792]$ & \\
\hline $\begin{array}{l}\text { Data/restraints/ } \\
\text { parameters }\end{array}$ & $10114 / 0 / 550$ & $5006 / 0 / 443$ \\
\hline $\begin{array}{l}\text { Goodness-of-fit on } \\
F^{2}\end{array}$ & 1.056 & 1.071 \\
\hline Final $R$ indices $[I>$ & $R_{1}=0.0409, \mathrm{w} R_{2}=$ & $R_{1}=0.0386, \mathrm{w} R_{2}=$ \\
\hline $\begin{array}{l}2 \sigma(I)] \\
R \text { indices (all data) }\end{array}$ & $\begin{array}{l}0.1065 \\
R_{1}=0.0447, \mathrm{w} R_{2}=\end{array}$ & $\begin{array}{l}0.0875 \\
R_{1}=0.0448, \mathrm{w} R_{2}=\end{array}$ \\
\hline & 0.1091 & 0.0905 \\
\hline
\end{tabular}

starting precursor. Furthermore, the bond angles of [O1-Cu-P1] $119.00(4)^{\circ}, \quad[\mathrm{N} 2-\mathrm{Cu}-\mathrm{P} 1] 125.13(5)^{\circ}, \quad[\mathrm{O} 1-\mathrm{Cu}-\mathrm{P} 2]$ 92.52(4) ${ }^{\circ}$, [N2-Cu-P2] $113.59(5)^{\circ},[\mathrm{N} 2-\mathrm{Cu}-\mathrm{O} 1] 79.08(6)^{\circ}$ and $[\mathrm{P} 1-\mathrm{Cu}-$ P2] $116.37(2)^{\circ}$ are deviated from the theoretical value of $109.28^{\circ}$. The bond lengths of $[\mathrm{Cu}-\mathrm{O} 1] 2.111(1) \AA,[\mathrm{Cu}-\mathrm{N} 2]$ 2.052(1) $\AA,[\mathrm{Cu}-\mathrm{P} 1] 2.2311(6) \AA$, and [Cu-P2] 2.3057(6) $\AA$ are almost equal to the tetrahedral bond lengths and are comparable with that of the other tetrahedral copper(I) complex. ${ }^{47}$ The unit cell packing of complex $\mathbf{3}$ is shown in the Fig. S1. $\dagger$

Structure of the minor product (3a) obtained along with $\mathbf{3}$ was solved using XRD and found to be $\left[\mathrm{CuCl}\left(\mathrm{PPh}_{3}\right)_{3}\right]$. The crystal structure, unit cell parameters, bond lengths of 3a was found to be in good agreement with the $\mathrm{Cu}(\mathrm{I})$ monovalent species reported earlier. ${ }^{48}$ Fig. 2 represents the crystal structure of complex 3a.

Complex 5. An ORTEP representation corresponding to the structure of $\left[\mathrm{Ni}\left(\mathrm{L}^{1}\right)_{2}\right]$ (5) inclusive of the atom numbering scheme is shown in Fig. 3 and its selected bond lengths and bond angles are presented in Tables 1 and 2. The title complex crystallized in the monoclinic unit cell with space group of $P 2_{1} / n$. The dimensions of both of the coordinated ligands are very similar and they adopted the enolate form. The Ni(II) center of complex 5 contained two bidentate hydrazone ligands and its crystallographic structural analysis revealed that the central metal atom adopts a distorted square planar geometry shared by two fused five-membered chelate rings $\{\mathrm{Ni1N} 1 \mathrm{~N} 2 \mathrm{C} 1 \mathrm{O} 1\}$ with its counterpart $\{\mathrm{Ni1N} 3 \mathrm{~N} 4 \mathrm{C} 8 \mathrm{O} 2\}$. Four atoms $(\mathrm{O} 1, \mathrm{O} 2, \mathrm{~N} 1, \mathrm{~N} 3)$ of the ligand $\left(\mathrm{L}^{1}\right)$ define a basal plane of the square plane by the replacement of both the chlorine and triphenylphosphines from 
Table 2 Selected bond lengths $(\AA)$ and bond angles $\left({ }^{\circ}\right)$

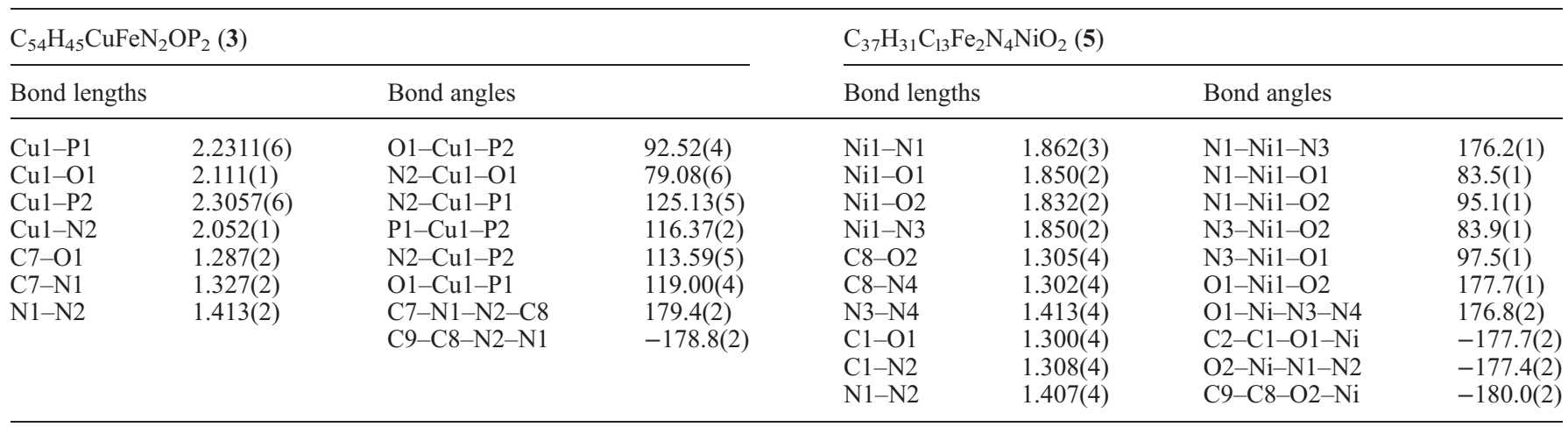

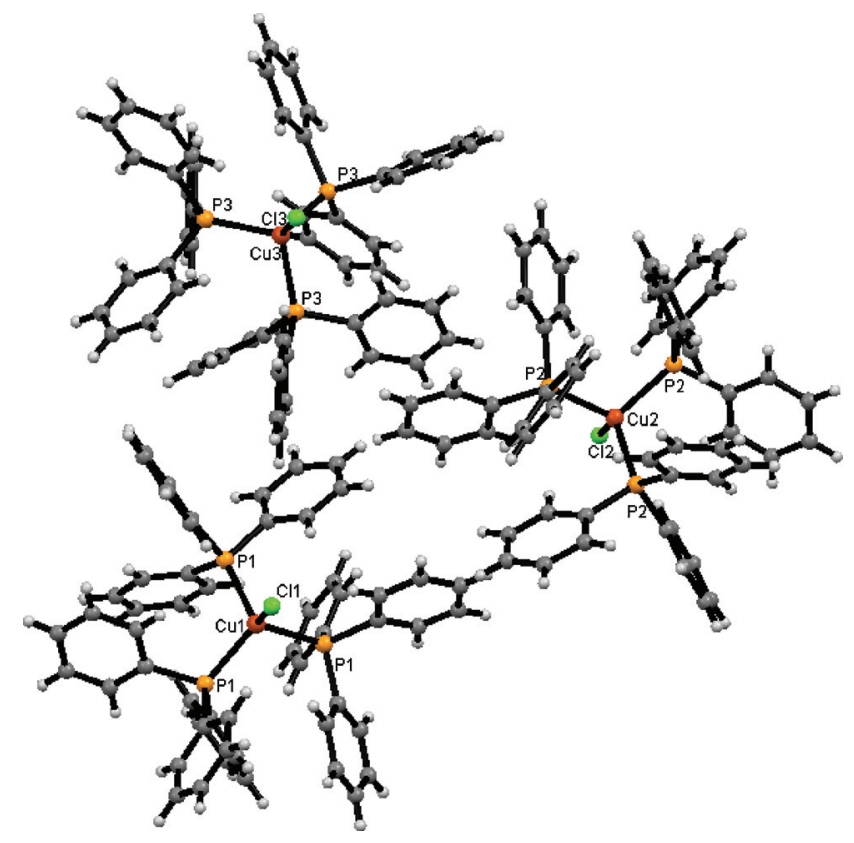

Fig. 2 Molecular structure of the complex 3a showing the atom-numbering scheme with thermal ellipsoids at $25 \%$ probability level.

the starting precursor. Furthermore, the bond angles of [O1-NiN1] 83.5(1) ${ }^{\circ}$, [N1-Ni-O2] 95.1(1) ${ }^{\circ},[\mathrm{O} 2-\mathrm{Ni}-\mathrm{N} 3]$ 83.9(1) ${ }^{\circ}$ and [O1-Ni-N3] $87.5(1)^{\circ}$ are found to be deviated from the theoretical value of $90^{\circ}$. The bond length of the basal planar bonds of

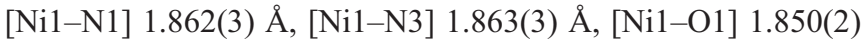
$\AA$, and [Ni1-O2] 1.832(2) $\AA$ are almost equal in length. These observations indicate that the coordination geometry of $\mathrm{Ni}$ (II) ion is a distorted square planar. In addition, a chloroform unit as a solvent molecule is also found in the structure of the complex. The unit cell packing of complex $\mathbf{5}$ is shown in Fig. S2.†

A possible explanation for the observed variation in the metalligand stoichiometry and the coordination geometry between copper and nickel complexes could be offered as herein. The observed reduction of $\mathrm{Cu}^{2+}$ to $\mathrm{Cu}^{1+}$ ion (complex 3 ) is accounted partly due to the presence of hydrazone ligand which generally acts as a good reducing agent ${ }^{49}$ and also partly due to the attainment of a more stable $\mathrm{t}_{2 \mathrm{~g}}{ }^{6} \mathrm{e}_{\mathrm{g}}{ }^{4}\left(\mathrm{~d}^{10}\right)$ configuration corresponding to copper(I) rather than less favourable $\mathrm{t}_{2 \mathrm{~g}}{ }^{6} \mathrm{e}_{\mathrm{g}}{ }^{3}\left(\mathrm{~d}^{9}\right)$ configuration of copper(II). Consequently, $\mathrm{Cu}(\mathrm{I})$ preferred tetrahedral over square planar geometry. However, in the case of complex $\mathbf{5}$, the reduction of diamagnetic $\mathrm{Ni}(\mathrm{II})$ from its $\mathrm{d}^{8}$ configuration with $\mathrm{t}_{2 \mathrm{~g}}{ }^{6} \mathrm{e}_{\mathrm{g}}{ }^{2}$ distribution to paramagnetic $\mathrm{Ni}(\mathrm{I})$ with $\mathrm{d}^{9}$ electronic configuration corresponding to $\mathrm{t}_{2 \mathrm{~g}}{ }^{6} \mathrm{eg}_{\mathrm{g}}{ }^{3}$ did not occur. However, similar $1: 2$ metal-ligand stoichiometry with square planar geometry could have resulted in the case of copper also, if the reduction of $\mathrm{Cu}$ (II) had not taken place.

\section{Infrared spectroscopy}

The IR spectra of the metal hydrazone complexes were compared with that of the respective free hydrazone ligands in the region 4000-200 $\mathrm{cm}^{-1}$. The spectra of the ligands $\mathbf{1}$ and $\mathbf{2}$ displayed characteristic absorption bands at 3224/3434, 1648/1636, $1555 / 1513$ and $1044 / 1035 \mathrm{~cm}^{-1}$ due to $v_{(\mathrm{N}-\mathrm{H})}, v_{(\mathrm{C}=\mathrm{O})}, v_{(\mathrm{C}=\mathrm{N})}$ and $v_{(\mathrm{N}-\mathrm{N})}$ vibrations, respectively. The bands due to $v_{(\mathrm{N}-\mathrm{H})}$ and $v_{(\mathrm{C}=\mathrm{O})}$ vibrations of the free ligands were absent for complexes 3-6, thus indicating that enolisation and deprotonation had taken place prior to coordination. This fact was further confirmed by the appearance of two new bands in the range $1599-1505 \mathrm{~cm}^{-1}$ and $1357-1372 \mathrm{~cm}^{-1}$ that corresponds to $v_{(\mathrm{C}=\mathrm{N}-\mathrm{N}=\mathrm{C})}$ and $v_{(\mathrm{C}-\mathrm{O})}$ stretching vibrations, respectively. The bands attributed to $v_{(\mathrm{C}=\mathrm{N})}$ stretching were shifted to lower frequencies while a positive shift of about $40-50 \mathrm{~cm}^{-1}$ was observed for $v_{(\mathrm{N}-\mathrm{N})}$ stretching vibration in comparison with that of their respective free ligands, thus implying that the nitrogen atom of the azomethine group is coordinated to the metal in these complexes. All these facts suggested that the hydrazone ligands behaves as a monobasic bidentate (NO) chelating ligand in each of the complexes $\mathbf{3}, \mathbf{4}, \mathbf{5}$ and 6.

\section{${ }^{1}$ H NMR spectroscopy}

${ }^{1} \mathrm{H}$ NMR spectra of the free hydrazone ligands and their complexes were assigned on the basis of observed chemical shift. The spectra of the ligands $\mathbf{1}$ and $\mathbf{2}$ displayed a weak singlet respectively at 9.04 and $9.12 \mathrm{ppm}$ due to $-\mathrm{NH}$ proton. Another sharp singlet observed at 8.31 and $8.54 \mathrm{ppm}$ are attributed to enolic $-\mathrm{OH}$ protons of the ligands $\mathbf{1}$ and $\mathbf{2}$ respectively. But, the NMR spectra of complexes 3-6 did not register any signals corresponding to either $-\mathrm{NH}$ or $-\mathrm{OH}$ and indicated that the ligands adopted the enol form, followed by deprotonation prior to coordination with the metal ion. In addition, both the ligands 


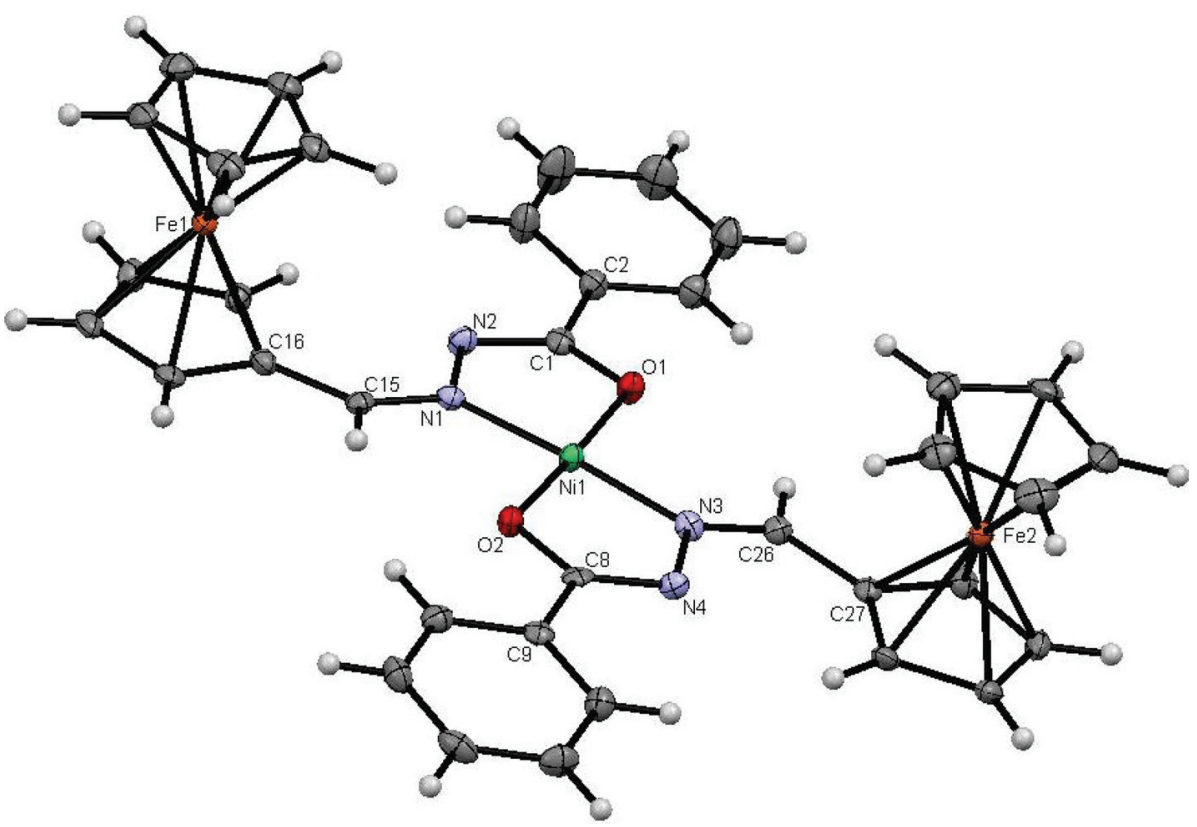

Fig. 3 The molecular structure of complex 5, with displacement ellipsoids drawn at the $50 \%$ probability level and the solvent molecule is omitted for clarity.

showed a sharp singlet for azomethine $(-\mathrm{HC}=\mathrm{N}-$ ) proton at 7.87 and $7.88 \mathrm{ppm}$, three singlets in the range of $3.81-4.73 \mathrm{ppm}$ for cyclopentadienyl moieties, respectively. However, in the case of spectra of complexes 3-6, the signal corresponds to the azomethine protons being shifted downfield due to the participation of azomethine nitrogen in coordination with metal ions. Similarly, the cyclopentadienyl signals also underwent a downfield shift upon coordination of the ligands with that of the respective metal ions. The signals corresponding to the protons of aromatic moieties of the ligands and their complexes were observed as multiplets in the range of $7-8 \mathrm{ppm}$.

\section{DNA binding studies}

Absorption spectral characteristics of DNA binding. Electronic absorption spectroscopy is usually employed to determine the binding ability of metal complexes with the DNA helix. Compounds that bound to DNA through intercalation are characterized by a change in absorbance (hypochromism) and bathochromic shift in wavelength, due to a strong stacking interaction between the aromatic chromophore of the test compounds and DNA base pairs. The extent of hypochromism is commonly consistent with the strength of intercalative interaction. ${ }^{50}$ The absorption spectra of ligands $\mathbf{1}$ and $\mathbf{2}$ and metal hydrazone complexes 3-6 in the absence and presence of CT DNA are shown in Fig. S3, S4, S5† and 4, respectively. The electronic spectrum of ligand 1 showed four well-resolved bands at 267, 301, 361 and $466 \mathrm{~nm}$. Similarly, the spectrum of ligand 2 exhibited its absorption bands at 262, 301, 372 and $470 \mathrm{~nm}$. The bands appearing in the range of 262-301 $\mathrm{nm}$ are assigned to intraligand charge transfer (ILCT) transitions. A broad shoulder found at 361 and $372 \mathrm{~nm}$ corresponds to ligand-to-metal (iron) charge transfer (LMCT) transitions and the band at 466 and $470 \mathrm{~nm}$ was assigned to charge transfer transition from iron to

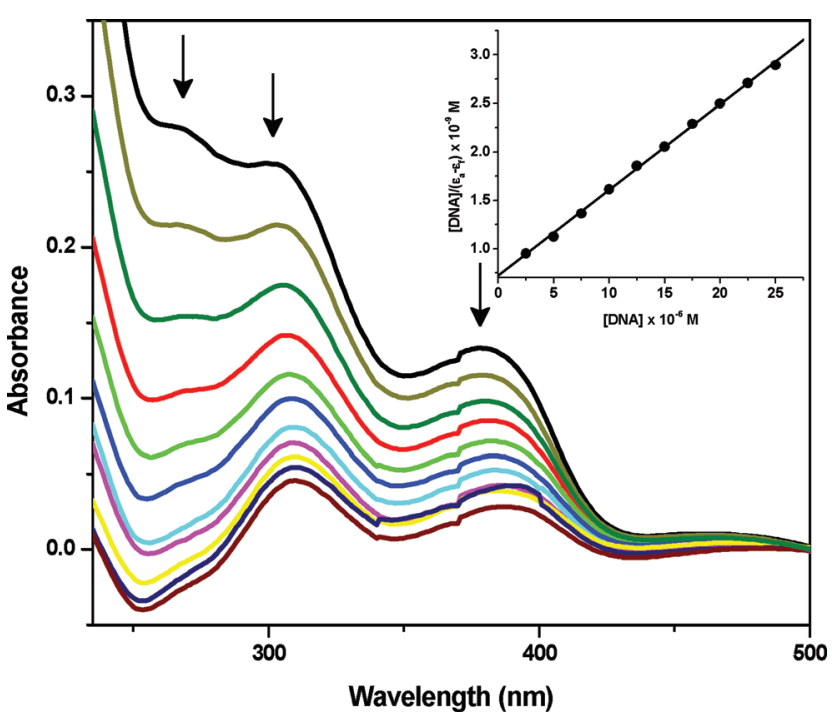

Fig. 4 Electronic absorption spectra of complex $6(25 \mu \mathrm{M})$ in the absence and presence of increasing amounts of CT DNA (2.5, 5.0, 7.5, $10.0,12.5,15.0,17.5$ and $20.0,22.5$ and $25 \mu \mathrm{M})$. Arrows show the changes in absorbance with respect to an increase in the DNA concentration (Inset: Plot between [DNA] and [DNA $] /\left[\varepsilon_{\mathrm{a}}-\varepsilon_{\mathrm{f}}\right]$ ).

either a non-bonding or an antibonding orbital of the cyclopentadienyl ring. ${ }^{51}$ Corresponding electronic spectrum of complexes 3-6 exhibited two or three bands in the range of 267 to $476 \mathrm{~nm}$. Complex 3 exhibited three different absorptions positioned at 303,343 and $384 \mathrm{~nm}$ whereas complex 4 showed only a couple of bands at 292 and $365 \mathrm{~nm}$. Similarly, complex 5 showed absorption bands at 298, 343 and $476 \mathrm{~nm}$, and complex 6 exhibited absorption bands at 267, 298 and $378 \mathrm{~nm}$. In general, the bands appearing in the 267-343 nm range in the case of all the complexes are due to intraligand $\pi \rightarrow \pi^{*}$ and $n \rightarrow \pi^{*}$ charge 
transfer (ILCT) transitions. ${ }^{52}$ The band at 384, 365 and $378 \mathrm{~nm}$ corresponding to complexes $\mathbf{3}, \mathbf{4}$ and $\mathbf{6}$ are due to LMCT transitions. The band appearing at $476 \mathrm{~nm}$ in the electronic spectrum of complex $\mathbf{5}$ is assigned to a metal-to-ligand charge transfer (MLCT) transition. With increasing CT DNA concentration, the absorption bands corresponding to hydrazone ligands $\mathbf{1}$ and $\mathbf{2}$ showed hypochromism of about $6.69,9.05,10.71,13.5,9.9,9.9$, 2.28 and $2.87 \%$ without any wavelength shift. However, in the case of complexes 3 and $\mathbf{4}$, we observed the same phenomenon of hypochromism $(19.17,30.04,29.85,43.51$ and $42.68 \%)$ with a bathochromic shift of about $0,3,3,7$ and $10 \mathrm{~nm}$ corresponding to the absorptions at $303,343,384,292$ and $365 \mathrm{~nm}$ respectively. Further, complex 5 exhibits hypochromism (68.43 and $65.53 \%$ ) with a bathochromic shift of about 5 and $7 \mathrm{~nm}$ at 298 and $343 \mathrm{~nm}$ respectively, whereas $1 \mathrm{~nm}$ hypsochromic shift with a hypochromism (61.53\%) was observed at $476 \mathrm{~nm}$. Complex 6 showed a significant hypochromism of about 109, 82.15 and $78.68 \%$ at 267,299 and $387 \mathrm{~nm}$ together with a bathochromic shift of 1,11 and $9 \mathrm{~nm}$, respectively. In order to compare the DNA-binding affinity of these compounds quantitatively, their intrinsic binding constants were calculated by the changes monitored in absorption at the higher energy band with increasing concentrations of DNA using the equation,

$$
[\mathrm{DNA}] /\left[\varepsilon_{\mathrm{a}}-\varepsilon_{\mathrm{f}}\right]=[\mathrm{DNA}] /\left[\varepsilon_{\mathrm{b}}-\varepsilon_{\mathrm{f}}\right]+1 / K_{\mathrm{b}}\left[\varepsilon_{\mathrm{b}}-\varepsilon_{\mathrm{f}}\right]
$$

Plotting [DNA] versus $[\mathrm{DNA}] /\left[\varepsilon_{\mathrm{a}}-\varepsilon_{\mathrm{f}}\right]$ gave a slope $1 /\left[\varepsilon_{\mathrm{a}}-\right.$ $\left.\varepsilon_{\mathrm{f}}\right]$ and a $y$ intercept equal to $1 / K_{\mathrm{b}}\left[\varepsilon_{\mathrm{b}}-\varepsilon_{\mathrm{f}}\right]$, respectively. The intrinsic binding constants $K_{\mathrm{b}}$ were calculated using the above plot and were found to be $3.874 \pm 0.050 \times 10^{3} \mathrm{M}^{-1}, 4.630 \pm$ $0.047 \times 10^{3} \mathrm{M}^{-1}, 2.449 \pm 0.042 \times 10^{4} \mathrm{M}^{-1}, 5.394 \pm 0.059 \times$ $10^{4} \mathrm{M}^{-1}, 8.371 \pm 0.038 \times 10^{4} \mathrm{M}^{-1}$ and $1.227 \pm 0.041 \times 10^{5}$ $\mathrm{M}^{-1}$ corresponding to the compounds 1-6, respectively. The magnitude of the binding constant value clearly showed that complex $\mathbf{6}$ bound more strongly with CT DNA than the rest of the compounds. Once the test compound intercalates to the base pairs of DNA, the $\pi^{*}$ orbital of the intercalators may couple with the $\pi$ orbital of the base pairs, thus decreasing the $\pi \rightarrow \pi^{*}$ transition probabilities and hence a hypochromism is observed in the above cases. ${ }^{53}$ These results are similar to those reported earlier for various classical intercalators. ${ }^{54,55}$

Circular dichroism. The results of electronic spectral studies of compounds 1-6 tentatively revealed an intercalative mode of binding of them with DNA. However, circular dichroism is a strong tool to identify the exact nature of binding between DNA and small molecules in order to probe the asymmetry of the system. The chirality of the DNA double helix originates from DNA geometry, resulting from the coupling of bases, phosphate backbone and chiral sugar units will be identified from CD spectral measurement. ${ }^{56}$ Although $\mathrm{CD}$ spectral changes cannot be interpreted on a quantitative basis, comparison of the experimental results with empirical spectra of representative DNA provides useful structural information. ${ }^{57}$ Fig. S6, S7† and 5 show the comparative CD spectra of pure CT-DNA and that of DNA treated with different concentrations of test compounds 1-6. The spectrum of pure DNA exhibited a positive band at $276 \mathrm{~nm}$ and a negative band at $245 \mathrm{~nm}$. Upon interaction of the test compounds 1-6 with DNA, these bands underwent perturbations as described herein. Addition of compounds 1-4 with DNA decreased the intensity of both the positive and negative ellipticity bands revealing that there occurred an electrostatic mode of binding between them without causing any conformational changes to it even after interaction with a higher concentration of the test solution. In addition, an increase in the molar ellipticity values of the above mentioned bands of DNA was observed by the addition of compounds 5 and $\mathbf{6}$ that reflected a single binding mode. The enhancement of these bands is a characteristic of groove binding that stabilizes the right handed B form of DNA. $^{58}$

\section{DNA cleavage}

The ability of metal hydrazone complexes to perform DNA cleavage is generally monitored by agarose gel electrophoresis and in the present work pUC19 plasmid DNA was chosen to investigate its cleavage. DNA cleavage was controlled by relaxation of the supercoiled circular form of pUC19 into the open circular form and linear form. When circular plasmid DNA is run on horizontal gel using electrophoresis, the supercoiled form will migrate first (Form I). If the strands of the selected DNA is cleaved by interaction with the metal complexes, the supercoils will relax to produce an open circular form (Form II) that moves slower than form I, whereas with cleavage of both strands to a linear form (Form III) the resulting system will migrate in between the above two forms. The tests were performed under aerobic conditions with $\mathrm{H}_{2} \mathrm{O}_{2}$ as a co-oxidant at a complex concentration of $35 \mu \mathrm{M}$. Neither $\mathrm{H}_{2} \mathrm{O}_{2}$ nor the metal complexes 3-6 yielded significant strand scission (not shown) when applied separately. These experimental facts demonstrated that a combination of both the metal hydrazone complexes and $\mathrm{H}_{2} \mathrm{O}_{2}$ are required to show effective cleavage of plasmid DNA. Fig. 6 reveals that cleavage of pUC19 DNA induced by complexes 3-6 in the presence of $\mathrm{H}_{2} \mathrm{O}_{2}$ results in the conversion of Form I (lane 1) into Form II (lane 2). The extent of Form I diminished gradually upon partial conversion to Form II with simultaneous increase in the intensity of the latter form. Based upon their ability to convert the supercoiled form (Form I SC) to the open circular form (Form II OC), it is obvious that complex 6 that possessed a hetero nitrogen containing pyridine moiety in its hydrazide part with square planar geometry which has more ability to cleave the supercoiled plasmid DNA when compared to that of the other complexes. These observations suggested that the cleavage of the supercoiled form to the open circular form increased in the order $\mathbf{3}<\mathbf{4}<\mathbf{5}<\mathbf{6}$. It is believed that the superior cleavage ability of complex $\mathbf{6}$ is due to the reaction of metal ions with $\mathrm{H}_{2} \mathrm{O}_{2}$, which produces diffusible hydroxyl radicals or molecular oxygen at ease, which in turn damage DNA through Fenton-type chemistry. ${ }^{59}$

\section{Protein binding studies}

Fluorescence quenching of BSA by copper and nickel hydrazone complexes. Generally, the fluorescence of a protein is caused by three intrinsic characteristics of the protein, namely tryptophan, tyrosine and phenylalanine residues. Fluorescence quenching refers to any process that decreases the fluorescence 

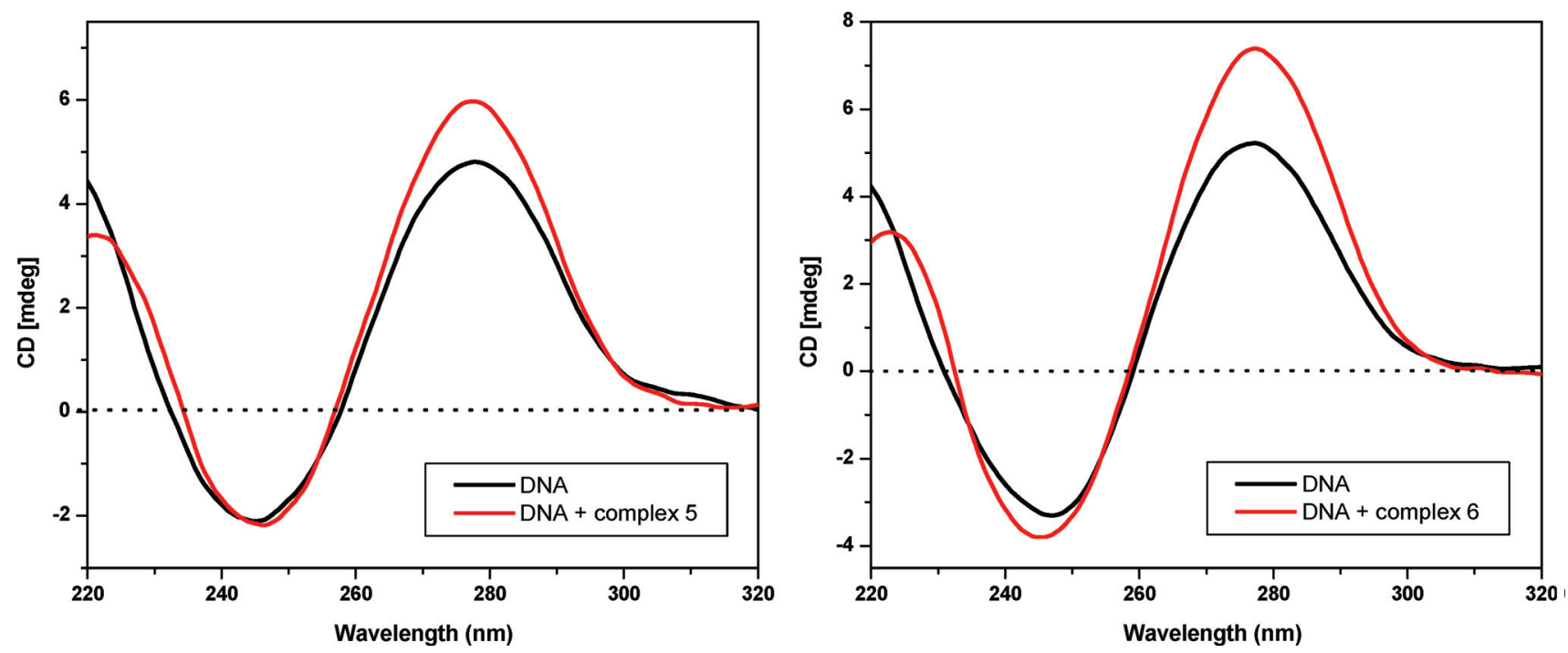

Fig. 5 Circular dichroic spectra of CT DNA $(200 \mu \mathrm{M})$ in the absence and presence of test complexes 5 and $\mathbf{6}(20 \mu \mathrm{M})$.

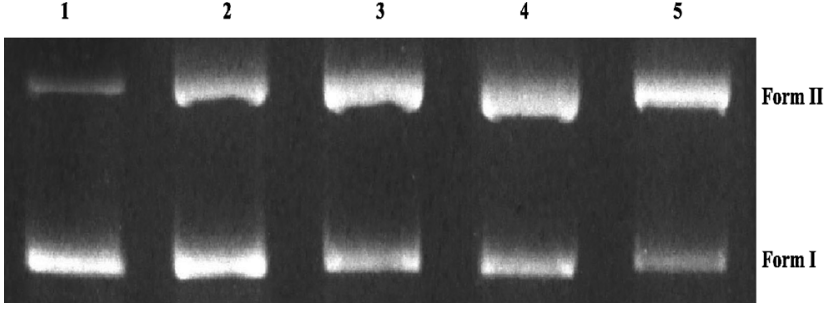

Fig. 6 Gel electrophoresis showing the chemical nuclease activity of the pUC19 DNA incubated at $37{ }^{\circ} \mathrm{C}$ for a period of $1 \mathrm{~h}$ at a concentration of $35 \mu \mathrm{M}$ of complex 3-6 in the presence of $\mathrm{H}_{2} \mathrm{O}_{2}(60 \mu \mathrm{M})$ as a co-oxidant: lane 1: $\mathrm{C}-$ pUC19 DNA $+\mathrm{H}_{2} \mathrm{O}_{2}$; lane 2: pUC19 DNA + $\mathrm{H}_{2} \mathrm{O}_{2}+$ complex 3; lane 3: pUC19 DNA $+\mathrm{H}_{2} \mathrm{O}_{2}+$ complex 4; lane 4: pUC19 DNA $+\mathrm{H}_{2} \mathrm{O}_{2}+$ complex 5; lane 5: pUC19 DNA $+\mathrm{H}_{2} \mathrm{O}_{2}+$ complex 6.

intensity of a fluorophore due to a variety of molecular interactions including excited-state reactions, molecular rearrangements, energy transfer, ground-state complex formation and collision quenching. Qualitative analysis of chemical compounds bound to BSA can be undertaken by examining the respective fluorescence spectra. Addition of the hydrazone ligands $\mathbf{1}$ and $\mathbf{2}$ to the solution of BSA does not result in the quenching of its fluorescence emission and hence, further studies of protein binding experiments were not carried out with respect to them. However, addition of copper and nickel hydrazone complexes 3-6 to BSA resulted in the quenching of fluorescence emission intensity along with a hypsochromic shift of 4 to $6 \mathrm{~nm}$ due to the formation of a complex between the metal hydrazone chelates and BSA. Fig. S8, S9† and 7 show the effect of increasing the concentration of metal hydrazone complexes on the fluorescence emission intensity of BSA.

The fluorescence quenching is described by the Stern-Volmer relation: $I_{0} / I=1+K_{\mathrm{SV}}$ [Q]; where $I_{0}$ and $I$ are the fluorescence intensities of the fluorophore in the absence and presence of quencher respectively, $K_{\mathrm{SV}}$ is the Stern-Volmer quenching constant and [Q] is the quencher concentration. $K_{\mathrm{SV}}$ value obtained

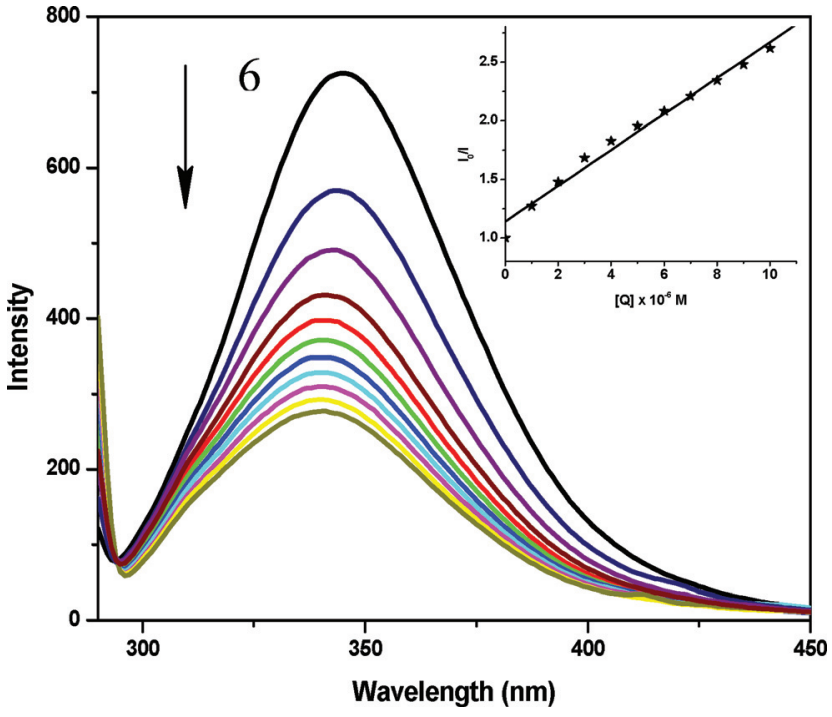

Fig. 7 Emission spectra of BSA $\left(1 \times 10^{-6} \mathrm{M} ; \lambda_{\text {exci }}=280 \mathrm{~nm} ; \lambda_{\text {emi }}=\right.$ $345 \mathrm{~nm})$ as a function of concentration of the complex $6(0,2,4,6,8$, 10,12 and $\left.14 \times 10^{-7} \mathrm{M}\right)$. Arrow indicates the effect of metal complex 6 on the fluorescence emission of BSA (Inset: Plot of [Q] vs. $I_{0} / I$ ).

from the plot of [Q] vs. $I_{0} / I$ (as insets of Fig. S8, S9† and 7) was found to be $6.985 \pm 0.140 \times 10^{4} \mathrm{M}^{-1}, 7.488 \pm 0.213 \times 10^{4} \mathrm{M}^{-1}$, $1.220 \pm 0.187 \times 10^{5} \mathrm{M}^{-1}$ and $1.528 \pm 0.122 \times 10^{5} \mathrm{M}^{-1}$ corresponding to the respective metal hydrazone chelates 3-6.

Binding analysis. The binding constant of the metal hydrazone complexes on binding with BSA can be calculated using the Scatchard equation, ${ }^{60}$

$$
\left(\Delta I_{0} / I\right) /[\mathrm{Q}]=n K-K\left(\Delta I_{0} / I\right)
$$

where, $n$ is the number of binding sites per albumin and $K$ is the association binding constant that is calculated from the slope in plots $\left(\Delta I_{0} / I\right) /[\mathrm{Q}]$ versus $\left(\Delta I_{0} / I\right)$ and $n$ is given by the ratio of $y$ intercept to the slope. The $K$ values of metal hydrazone 


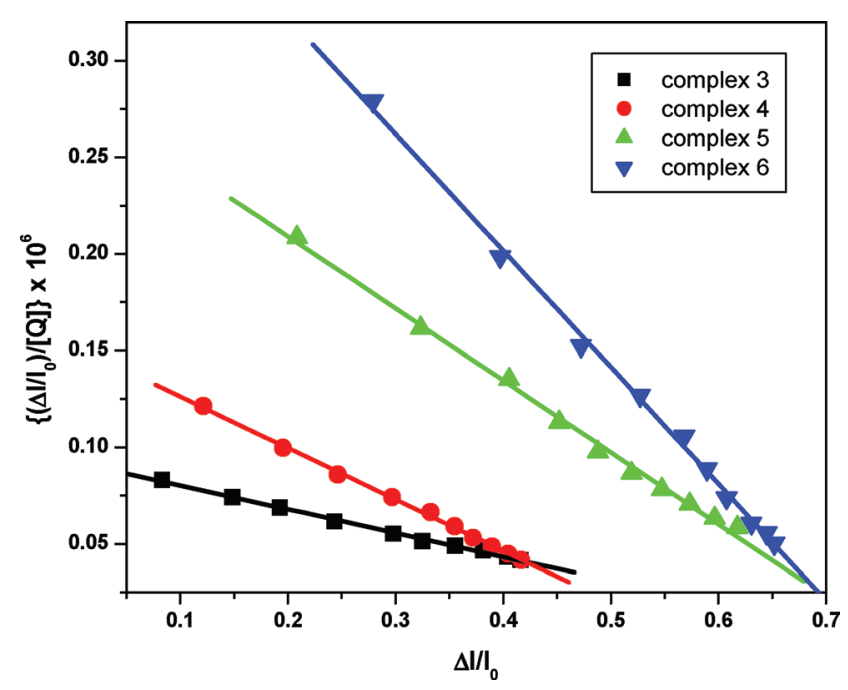

Fig. 8 Plot of $\left(\Delta I_{0} / I\right) /[\mathrm{Q}]$ versus $\left(\Delta I_{0} / I\right)$.

Table 3 Comparison of interaction study results between compounds 1-6 on DNA and protein

\begin{tabular}{lllll}
\hline \multirow{5}{*}{ Compounds } & $\begin{array}{l}\text { DNA binding } \\
K_{\mathrm{b}}\left(\mathrm{M}^{-1}\right)\end{array}$ & $K_{\mathrm{sv}}\left(\mathrm{M}^{-1}\right)$ & $K\left(\mathrm{M}^{-1}\right)$ & $n$ \\
\hline $\mathbf{1}$ & $3.874 \pm 0.050$ & - & - & - \\
& $\times 10^{3}$ & & & \\
$\mathbf{2}$ & $4.630 \pm 0.047$ & - & - & - \\
$\mathbf{3}$ & $\times 10^{3}$ & & & \\
& $2.449 \pm 0.042$ & $6.985 \pm 0.140$ & $1.260 \pm 0.010$ & 0.6741 \\
$\mathbf{4}$ & $\times 10^{4}$ & $\times 10^{4}$ & $\times 10^{5}$ & \\
& $5.394 \pm 0.059$ & $7.488 \pm 0.213$ & $2.662 \pm 0.008$ & 0.6930 \\
$\mathbf{5}$ & $\times 10^{4}$ & $\times 10^{4}$ & $\times 10^{5}$ & \\
& $8.371 \pm 0.038$ & $1.220 \pm 0.187$ & $3.725 \pm 0.021$ & 0.7341 \\
$\mathbf{6}$ & $\times 10^{4}$ & $\times 10^{5}$ & $\times 10^{5}$ & \\
& $1.227 \pm 0.041$ & $1.528 \pm 0.122$ & $6.037 \pm 0.027$ & 0.7613 \\
& $\times 10^{5}$ & $\times 10^{5}$ & $\times 10^{5}$ & \\
\hline
\end{tabular}

complexes 3-6 obtained from the Scatchard plots (Fig. 8) according to the above mentioned equation are found to be $1.260 \pm 0.010 \times 10^{5} \mathrm{M}^{-1}, 2.662 \pm 0.008 \times 10^{5} \mathrm{M}^{-1}, 3.725 \pm$ $0.021 \times 10^{5} \mathrm{M}^{-1}$ and $6.037 \pm 0.027 \times 10^{5} \mathrm{M}^{-1}$, respectively.

From the DNA binding and BSA binding results (Table 3), it is clear that among the ligands $\mathrm{HL}^{1}$ and $\mathrm{HL}^{2}$, the latter with a heterocyclic moiety containing a pyridine ring in its molecular structure showed higher binding affinity with DNA when compared to the former with the phenyl ring in its acid hydrazide part. In general, the binding affinities of metal chelates towards DNA are better than that of the ligands due to the chelate effect. The overall order of binding affinity (DNA/BSA) increased in the order $\mathbf{1}<\mathbf{2}<\mathbf{3}<\mathbf{4}<\mathbf{5}<\mathbf{6}$. This observed trend suggested that the complexes $\mathbf{5}$ and $\mathbf{6}$ with more planar square planar geometry exhibited strong binding affinity than the corresponding copper complexes $\mathbf{3}$ and $\mathbf{4}$ possessing a less planar tetrahedral arrangement. Also, it was found that complex $\mathbf{6}$ containing the hetero nitrogen atom (pyridine ring) in its hydrazide moiety has a strong interaction towards DNA/BSA than that of the other (complex 5) that didn't have a similar nitrogen atom in its hydrazide part. Similar observations have also been noted between the

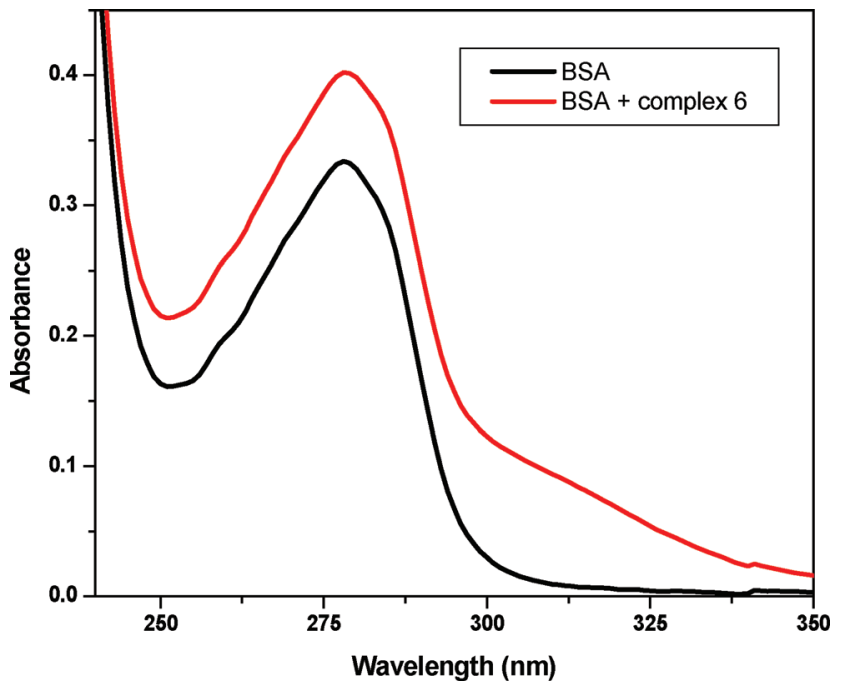

Fig. 9 The absorption spectra of BSA $\left(1 \times 10^{-5} \mathrm{M}\right)$ and BSAcomplex $6\left(\mathrm{BSA}=1 \times 10^{-5} \mathrm{M}\right.$ and complex $\left.6=1 \times 10^{-6} \mathrm{M}\right)$.

copper complexes $\mathbf{3}$ and $\mathbf{4}$ and the overall order of binding affinity of the complexes is found as $\mathbf{6}>\mathbf{5}>\mathbf{4}>\mathbf{3}$. These results did indicate that in addition to the planarity, the number of ferrocene units and the presence of hetero nitrogen atom in the structure of the complexes have also influenced their affinity towards DNA/BSA binding.

UV-visible absorption measurements. The quenching process can occur by different mechanisms, classified as dynamic quenching and static quenching. Dynamic quenching refers to a process in which the fluorophore and the quencher come into contact during the transient existence of the excited state while static quenching refers to fluorophore-quencher complex formation in the ground state. A simple method to explore the type of quenching is UV-visible absorption spectroscopy. The absorption band obtained for BSA at $278 \mathrm{~nm}$ in the absence of metal hydrazone complexes showed an increase in the intensity of absorption after the addition of complexes 3, 4, 5 and 6 revealing that there exists a static interaction between BSA and the respective complexes due to the formation of ground state complexes of the type BSA-complex as reported earlier. ${ }^{61}$ Representative absorption spectra of pure BSA and BSAcomplex $\mathbf{6}$ are shown in Fig. 9.

Characteristics of synchronous fluorescence spectra. To investigate the structural changes which occurred to BSA upon the addition of copper and nickel hydrazone complexes, we measured synchronous fluorescence spectra of BSA respectively before and after the addition of metal hydrazone complexes to get valuable information on the molecular microenvironment, particularly in the vicinity of the fluorophore functional groups. ${ }^{62}$ It is a well known fact that the fluorescence of BSA is normally due to the presence of tyrosine, tryptophan and phenylalanine residues and hence spectroscopic methods are usually applied to study the conformation changes of serum protein. According to Miller, ${ }^{63}$ in synchronous fluorescence spectroscopy, the difference between excitation and emission wavelength $\left(\Delta \lambda=\lambda_{\text {emi }}-\lambda_{\text {exc }}\right)$ reflects the spectra of a different nature 

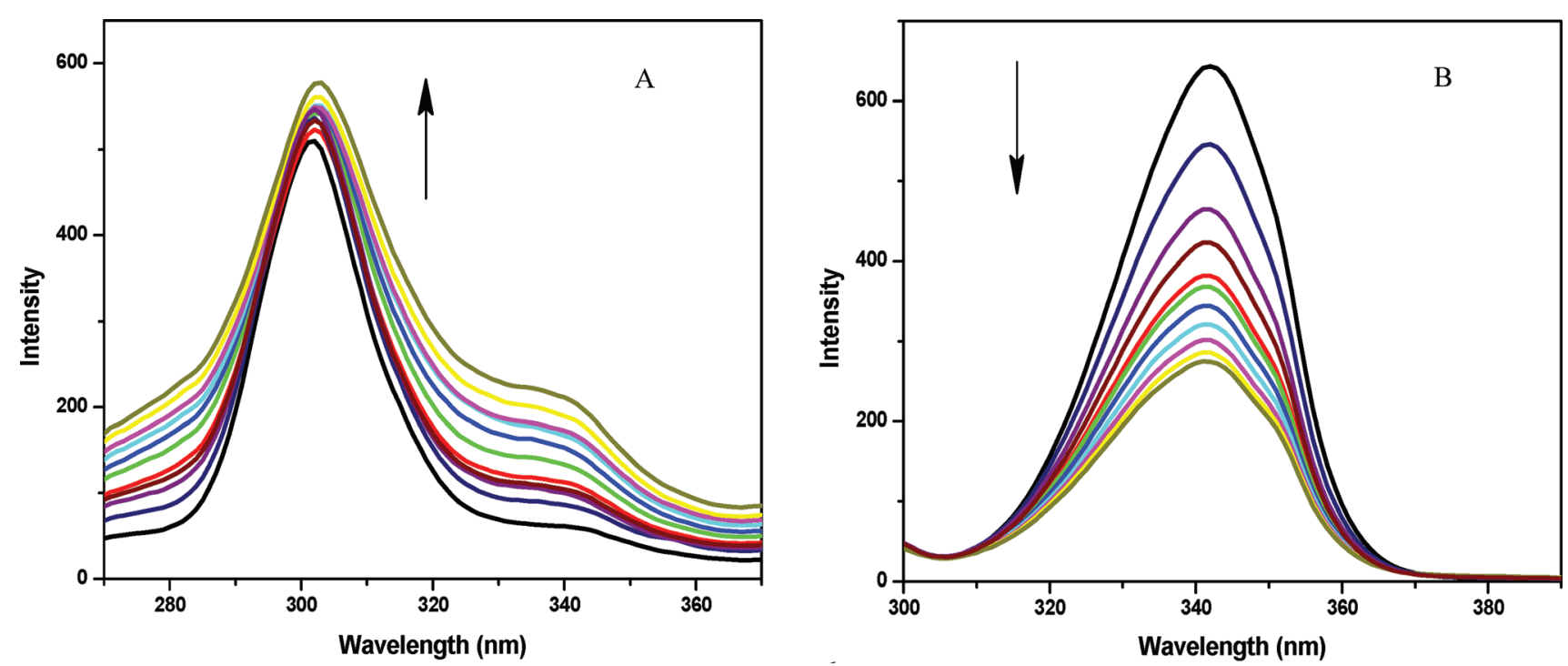

Fig. 10 Synchronous spectra of BSA $\left(1 \times 10^{-6} \mathrm{M}\right)$ as a function of concentration of the complex $6\left(0,2,4,6,8,10,12,14,16,18\right.$ and $20 \times 10^{-7}$ M) with wavelength difference of $\Delta \lambda=15 \mathrm{~nm}$ (A) and $\Delta \lambda=60 \mathrm{~nm}$ (B). Arrow indicates changes in emission intensity w.r.t various concentrations of complex 6.

of chromophores. If the $\Delta \lambda$ value is small $(15 \mathrm{~nm})$ the synchronous fluorescence of BSA is characteristic of a tyrosine residue whereas a larger $\Delta \lambda$ value of $60 \mathrm{~nm}$ is characteristic of tryptophan. ${ }^{64}$ The synchronous fluorescence spectra of BSA upon the addition of copper and nickel hydrazone complexes recorded with using two different $\Delta \lambda$ values i.e., $\Delta \lambda=15$ and $60 \mathrm{~nm}$ are shown in Fig. S10, S11, S12 $\uparrow$ and 10. From these spectra, it became clear that an increase in the concentration of the metal hydrazone complexes added to BSA also increased (very slightly) the intensity of the synchronous fluorescence spectral band corresponding to the tyrosine residue in the case of complexes $\mathbf{3}$ and $\mathbf{4}$ whereas complexes $\mathbf{5}$ and $\mathbf{6}$ showed an increase in the intensity of the same band along with a bathochromic shift of $1 \mathrm{~nm}$. This shows that complexes $\mathbf{5}$ and $\mathbf{6}$ affected tyrosine residues whereas complexes $\mathbf{3}$ and $\mathbf{4}$ did not affect the environment in the above said region. In addition, a significant decrease of fluorescence intensity of tryptophan residues with a slight blue-shift of emission wavelength was found after the addition of complexes 3-6. These results indicated that though the complexes $\mathbf{5}$ and $\mathbf{6}$ affected both the micro environments i.e., tyrosine and tryptophan residues, the effect was more towards tryptophan residues than tyrosine residue whereas complexes $\mathbf{3}$ and $\mathbf{4}$ affected only the tryptophan residue but not the other. The features of synchronous measurements confirmed that conformational changes occurred in BSA upon interaction with the complexes. Similar behaviour regarding the interaction between the BSA and metal hydrazone complexes was reported earlier. ${ }^{65}$

\section{Antioxidant activity}

It is a well documented fact that hydrazones and their corresponding transition metal complexes displayed significant antioxidant activity ${ }^{66-68}$ and therefore we undertook a systematic investigation on the antioxidant potential of free hydrazone ligands $\mathbf{1}$ and $\mathbf{2}$ and corresponding transition metal complexes $\mathbf{3}$,
4, 5 and 6 against DPPH, $\mathrm{OH}$ and $\mathrm{NO}$ radicals with respect to different concentrations of the test compounds varying from 0 to $50 \mu \mathrm{M}$ (Fig. 11) and the results were shown in Table 4. From Table 4, it can be concluded that a much less or no scavenging activity was exhibited by the free ligands when compared to that of their corresponding metal hydrazone complexes which is due to the chelation of them with the metal ions. Among the structurally different copper and nickel complexes, the scavenging potential of nickel complexes are better than the respective copper hydrazone chelates that can be related to the ligand occupancy with that of the metal ions. However, among the copper and nickel hydrazone complexes, the one containing a pyridine ring (complex $\mathbf{4}$ and $\mathbf{6}$ ) in the hydrazide moiety showed higher antioxidant activity than the complexes $\mathbf{3}$ and $\mathbf{5}$ which did not have such a molecular composition. The overall scavenging activity of the tested compounds was found to increase in the order of $\mathbf{1}<\mathbf{2}<\mathbf{3}<\mathbf{4}<\mathbf{5}<\mathbf{6}$. Further, the results obtained against the three different radicals confirmed that the complexes are more effective to arrest the formation of DPPH than the hydroxyl and nitric oxide radicals and are compared with that of the other copper and nickel complexes. ${ }^{69}$ The lower $\mathrm{IC}_{50}$ values observed in antioxidant assays did demonstrate that these complexes have a strong potential to be applied as scavengers to eliminate the radicals. Further, it is significant to mention that the metal complexes synthesised herein possess superior antioxidant activity against the above said radicals than that of the standard antioxidant butylated hydroxyl anisole (BHA).

\section{Cytotoxicity}

Cytotoxicity is a common limitation in terms of the introduction of new compounds into the pharmaceutical industry. In general, heteronuclear organometallic complexes exhibit potential cytotoxicity with dose-response effects. In order to understand the in vitro cytotoxicity of the metal hydrazone complexes, 

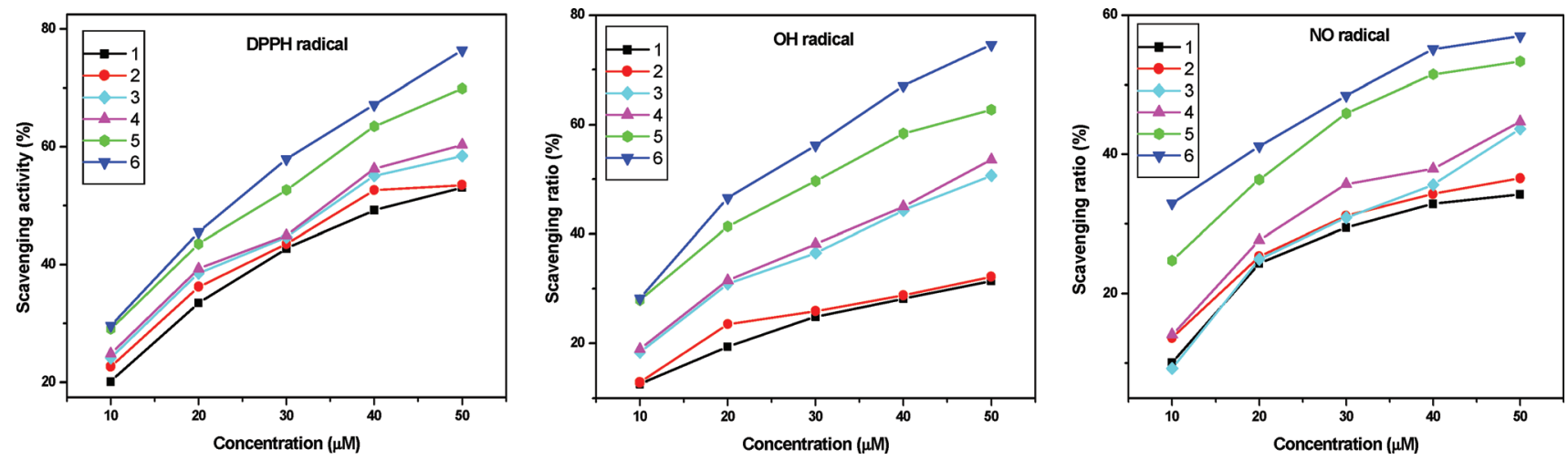

Fig. 11 Trends in the inhibition of DPPH, OH and NO radicals by ligands $\mathbf{1}$ and $\mathbf{2}$ and corresponding metal complexes $\mathbf{3}, \mathbf{4 , 5}$ and $\mathbf{6}$ at various concentrations.

Table 4 Comparison of $\mathrm{IC}_{50}$ values of test compounds towards selected free radicals

\begin{tabular}{llll}
\hline & \multicolumn{3}{l}{$\mathrm{IC}_{50}$ values $(\mu \mathrm{M})$} \\
\cline { 2 - 4 } Test compounds & $\begin{array}{l}\text { DPPH } \\
\text { radical }\end{array}$ & $\begin{array}{l}\text { Hydroxyl } \\
\text { radical }\end{array}$ & $\begin{array}{l}\text { Nitric oxide } \\
\text { radical }\end{array}$ \\
\hline $\mathbf{1}$ & 42.17 & - & - \\
$\mathbf{2}$ & 37.68 & - & - \\
$\mathbf{3}$ & 35.21 & 49.53 & - \\
$\mathbf{4}$ & 34.72 & 45.48 & - \\
$\mathbf{5}$ & 27.39 & 30.56 & 37.43 \\
$\mathbf{6}$ & 22.05 & 23.81 & 31.89 \\
$\begin{array}{l}\text { Reported value } \\
\text { (Cu) }\end{array}$ & 20.16 & 21.37 & 7.65 \\
$\begin{array}{l}\text { Reported value } \\
\text { (Ni) }\end{array}$ & 35.66 & 38.46 & 10.11 \\
\hline
\end{tabular}

experiments were carried out using a panel of cell lines namely HeLa, A314 (tumor cells) and NIH 3 T3 (normal cells) by colorimetric (MTT) assay in which mitochondrial dehydrogenase activity was measured as an indication of cell viability. Complexes were dissolved in DMSO and the blank samples containing the same volume of DMSO were taken as controls to identify the activity of solvent against the selected cell lines. Cisplatin was used as a standard to assess the cytotoxicity of complexes 3, 4, 5 and 6 (not shown). ${ }^{70,71}$ The capabilities of the above said complexes to arrest the proliferation of tumor cells without causing any damage to normal cells were evaluated after $48 \mathrm{~h}$ of incubation. The results were analyzed by means of cell viability curves and expressed with $\mathrm{IC}_{50}$ values in the studied concentration range from $12.5-400 \mu \mathrm{M}$. Upon increasing the concentration of complexes, the results of MTT assays revealed that complexes $\mathbf{3}$ and $\mathbf{4}$ completely failed to arrest the growth of both HeLa and A431 tumor cell lines (up to a concentration of $400 \mu \mathrm{M}$ ) but complexes 5 and 6 (Table 5) showed notable activity against both the cell lines mentioned above with respective $\mathrm{IC}_{50}$ values of $92.86,49.48,80.72$ and $35.13 \mu \mathrm{M}^{72}$ A valid reason for the inactiveness of copper complexes (3 and 4) but a significant activity of nickel complexes (5 and 6) against the selected tumour cell lines can be offered in relation to the variable ligand occupancy with that of the respective metal ions i.e., copper and nickel such as $1: 1$ have a less planar tetrahedral geometry and $2: 1$ have a more planar square planar geometry
Table 5 Comparison of $\mathrm{IC}_{50}$ values of complexes $\mathbf{5}$ and $\mathbf{6}$ on treatment with NIH 3T3, HeLa and A431 cells

\begin{tabular}{|c|c|c|c|}
\hline \multirow[b]{2}{*}{ Complex } & \multicolumn{3}{|c|}{$\mathrm{IC}_{50}$ values $(\mu \mathrm{M})$} \\
\hline & NIH $3 \mathrm{~T} 3$ & $\mathrm{HeLa}$ & A 431 \\
\hline 5 & 312.44 & 92.86 & 80.72 \\
\hline 6 & 188.53 & 49.48 & 35.13 \\
\hline
\end{tabular}

respectively. From the above $\mathrm{IC}_{50}$ values, it became clear that complex $\mathbf{6}$ has more potential than complex $\mathbf{5}$ due to the presence of a pyridine ring in the hydrazide moiety of the coordinated ligand in the former complex. Among the two different cell lines used in this study, the proliferation of A431 was arrested to a greater extent than HeLa cells by the complexes. Though the above set of complexes are active against the cell lines under in vitro cytotoxicity experiments, none of them could reach the effectiveness shown by the standard drug cisplatin $\left(\mathrm{IC}_{50}=16.1\right.$ and $14.4 \mu \mathrm{M}$, respectively $) .{ }^{70}$ Upon treatment of the complexes 3-6 against normal NIH 3T3 cells, 3 and $\mathbf{4}$ did not show any damage to healthy cells but very less damage was induced by complexes 5 and $\mathbf{6}\left(\mathrm{IC}_{50}=312.44\right.$ and $188.53 \mu \mathrm{M}$, respectively) to healthy cells. The results of the cell viability tests imply that the complexes $\mathbf{5}$ and $\mathbf{6}$ have the ability to arrest the proliferation of tumor cells without causing perceptible damage to the normal cells.

\section{Conclusion}

In the present study, a set each of univalent copper and bivalent nickel complexes containing ferrocene derived hydrazones have been synthesized from the reactions of respective $\mathrm{Cu}$ (II) and $\mathrm{Ni}$ (II) precursors and hydrazones in $1: 1$ stoichiometric ratio and characterised using different physico-chemical techniques including single crystal XRD. Interestingly, in the reactions involving copper(II) starting precursor, reduced $\mathrm{Cu}$ (I) hydrazone complexes of 1:1 metal-ligand occupancy with a tetrahedral structure were formed, whereas, square planar complexes with $1: 2$ ligand occupancy was realized in the case of nickel(II) starting precursor. The outcome of various biological experiments did indicate that complexes $\mathbf{5}$ and $\mathbf{6}$ containing nickel(II) ion with 
a square planar geometry contributed by 2 molecules of hydrazones had more potential than that of the complexes $\mathbf{3}$ and $\mathbf{4}$ having cuprous ion in a less planar tetrahedral geometry with a single hydrazone moiety along with a pair of sterically crowded triphenylphosphine that hinders a close approach towards DNA, BSA etc. Among the bivalent nickel or the monovalent copper hydrazone chelates, the one (complex 6 or 4 ) containing a heterocyclic pyridine moiety in its molecular architecture showed a more pronounced effect in the biological experiments than the other (complex $\mathbf{5}$ or $\mathbf{3}$ ) possessing a phenyl ring instead of a pyridine ring. These observations have shed some light on the relation between the geometry as well as elemental composition of the complexes and their reactivity with various biomolecules.

\section{Acknowledgements}

We express our gratitude to Prof. A. Ramu and Prof. K. Pitchumani, School of Chemistry, Madurai Kamaraj University, India, for their help to record CD spectra. Also, we thank University Grants Commission, New Delhi, India, for the Fellowship in Science for Meritorious Students (RFSMS) to Mr. P. Krishnamoorthy and Department of Science and Technology, Government of India, New Delhi, for the award of Senior Research Fellowship (SRF) to Ms.P. Sathyadevi. AHC is grateful to the Robert A. Welch Foundation (Grant F-0003) for financial support of this work.

\section{References}

1 M. V. Angelusiu, S. F. Barbuceanu, C. Draghici and G. L. Almajan, Eur. J. Med. Chem., 2010, 45, 2055-2062.

2 S. Naskar, S. Naskar, R. J. Butcher and S. K. Chattopadhyay, Inorg. Chim. Acta, 2010, 363, 404-411.

3 H. G. Aslan, S. Ozcan and N. Karacan,, Inorg. Chem. Commun., 2011, 14, 1550-1553.

4 Q. Wang, Z. Y. Yang and G. F. Qi, BioMetals, 2009, 22, 927-940.

5 Z. Xu, X. Zhang, W. Zhang, Y. Gao and Z. Zeng, Inorg. Chem. Commun., 2011, 14, 1569-1573.

6 F. Kratz, V. Beyer, T. Roth, N. Tarasova, P. Collery, F. Lechenault, A. Cazabat, P. Shumacher, C. Unger and U. Falkem, J. Pharm. Sci., 1998, 87, 338-346.

7 A. Benito, J. Cano, R. Martinez-Manez, A. Benito, J. Cano, R. MartinezManez, J. Soto, J. Paya, F. Lloret, M. Julve, J. Faus and M. D. Marcos, Inorg. Chem., 1993, 32, 1197-1203.

8 M. Bracci, C. Ercolani, B. Floris, M. Bassetti, A. Chiesi-Vila and C. Guastini, J. Chem. Soc., Dalton Trans., 1990, 1357-1364.

9 Y. X. Ma and G. Zhao, Polyhedron, 1988, 7, 1101-1105.

10 G. Zhao, F. Li, J. Xie and Y. X. Ma, Polyhedron, 1988, 7, 393-398.

11 G. Zhao and Y. X. Ma, Polyhedron, 1999, 10, 2185-2189.

12 E. I. Edwards, R. Epton and G. Marr, J. Organomet. Chem., 1975, 85, $\mathrm{C} 23-\mathrm{C} 25$

13 M. Cais, S. Dani, Y. Eden, O. Gandolfi, M. Horn, E. E. Issaacs, Y. Josephy, Y. Saar, E. Slovin and L. Snarsky, Nature, 1977, 270, 534 535.

14 S. G. Clarkson and F. Basolo, Inorg. Chem., 1973, 12, 1528-1534.

15 B. B. Wayland, M. E. A. Elmageed and L. F. Mehne, Inorg. Chem., $1975, \mathbf{1 4}, 1456-1460$.

16 B. G. Malmstrom and J. Leckner, Curr. Opin. Chem. Biol., 1998, 2, 286292.

17 E. I. Solomon, U. M. Sundaram and T. E Machonkin, Chem. Rev., 1996, 96, 2563-2605.

18 E. I. Solomon, P. Chen, M. Metz, S. K. Lee and A. E. Palmer, Angew. Chem., Int. Ed., 2001, 40, 4570-4590.

19 E. I. Solomon, F. Tuczek, D. E. Root and C. A. Brown, Chem. Rev, 1994, 94, 827-856.
20 P. M. Colman, H. C. Freeman, J. M. Guss, M. Murata, V. A. Norris, J. A. M. Ramshaw and M. P. Venkatappa, Nature, 1978, 272, 319-324.

21 R. Durley, L. Chen, F. S. Mathews, L. W. Lim and V. L. Davidson, Protein Sci., 1993, 2, 739-752.

22 P. J. Hart, D. Eisenberg, A. M. Nersissian, J. S. Valentine, R. G. Herrmann and R. M. Nalbandyan, Protein Sci., 1996, 5, 2175-2183.

23 N. Shibata, T. Inoue, C. Nagano, N. Nishio, T. Kohzuma, K. Onodera, F. Yoshizaki, Y. Sugimura and Y. Kai, J. Biol. Chem., 1999, 274, 42254230.

24 J. N. Chan, Z. Y. Huang, M. E. Merrifield, M. T. Salgado and M. Stillman, Coord. Chem. Rev., 2002, 233-234, 319-339.

25 A. Colak, U. Terzi, M. Col, S. A. Karaoglu, S. Karabocek, A. Kucukdumlu and F. A. Ayaz, Eur. J. Med. Chem., 2010, 45, 51695175

26 P. B. Kandagal, S. Ashoka, J. Seetharamappa, S. M. T. Shaikh, Y. Jadegoud and O. B. Ijare, J. Pharm. Biomed. Anal., 2006, 41, 393399.

27 X. Zhu, J. Sun and Y. Hu, Anal. Chim. Acta, 2007, 596, 298-302.

28 Y. Q. Wang, H. M. Zhang and G. C Zhang, J. Pharm. Biomed. Anal., 2006, 41, 1041-1046.

29 A. Kamal, R. Ramu, V. Tekumalla, G. B. R. Khanna, M. S. Barkume, A. S. Juvekar and SM. Zingde, Bioorg. Med. Chem., 2007, 15, 68686875.

30 S. Rauf, J. J. Gooding, K. Akhtar, M. A. Ghauri, M. Rahman and M. A. Anwar, J. Pharm. Biomed. Anal., 2005, 37, 205-217.

31 M. Asadi, E. Safaei, B. Ranjbar and L. Hasani, New J. Chem., 2004, 28, $1227-1234$.

32 J. Wang, G. Rivas, M. Ozsoz, D. H. Grant, X. Cai and C. Parrado, Anal. Chem., 1997, 69, 1457-1460.

33 F. L. Cui, J. L. Wang, Y. R. Cui and J. P. Li, Anal. Chim. Acta, 2006, 571, 175-183.

34 L. Shang, X. Jiang and S. Dong, J. Photochem. Photobiol., A, 2006, 184, 93-97.

35 G. M. Sheldrick, SHELXTL-PC (Version 5.03), Siemens Analytical X-ray Instruments Inc., Madison, Wisconsin, USA, 1994.

36 G. M. Sheldrick, Acta Crystallogr., Sect. A: Found. Crystallogr., 2007, 64, 112-122.

37 A. L. Spek, Acta. Crystallogr. A, 1990, 46, C34.

38 L. M. Venanzi, J. Am. Chem. Soc., 1958, 719-724.

39 G. N. Rao, Ch. Janardhana, K. Pasupathy and P. Mahesh Kumar, Ind. J. Chem., 2000, 39B, 151-153.

40 H. Chao, W. Mei, Q. Huang and L. Ji, J. Inorg. Biochem., 2002, 92, $165-$ 170.

41 P. Lincoln, E. Tulite and B. Norden, J. Am. Chem. Soc., 1997, 119, $1454-1455$.

42 B. Norden and F. Tjerneld, Biopolymers, 1982, 21, 1713-1734.

43 J. Bernadou, G. Pratviel, F. Bennis, M. Girardet and B. Meunier, Biochemistry, 1989, 28, 7268-7275.

44 M. S. Blois, Nature, 1958, 181, 1199-1200.

45 T. Nash, Biochem. J., 1953, 55, 416-421.

46 L. C. Green, D. A. Wagner, J. Glogowski, P. L. Skipper, J. S. Wishnok and S. R. Tannenbaum, Anal. Biochem., 1982, 126, 131-138.

47 I. Garcia-Orozco, C. Ortega-Alfaro Ma, J. G. Lo Pez-Cortes, R. Alfredo Toscano and C. Alvarez-Toledano, Inorg. Chem., 2006, 45, 1766-1773.

48 P. Krishnamoorthy, P. Sathyadevi, K. Senthil Kumar, P. Thomas Muthiah, R. Ramesh and N. Dharmaraj, Inorg. Chem. Commun., 2011, 14, 13181322.

49 L. El Sayed and M. F. Iskander, J. Inorg. Nucl. Chem., 1971, 33, 435443.

50 S. A. Tysoe, R. J. Morgan, A. D. Baker and T. C. Strekas, J. Phys. Chem., 1993, 97, 1707-1711.

51 P. Barbazan, R. Carballo, U. Abram, G. Pereiras-Gabian and E. M. Vazquez-Lopez, Polyhedron, 2006, 25, 3343-3348.

52 A. Ray, S. Banerjee, R. J. Butcher, C. Desplanches and S. Mitra, Polyhedron, 2008, 27, 2409-2415.

53 T. R. Li, Z. Y. Yang, B. D. Wang and D. D. Qin, Eur. J. Med. Chem., $2008,43,1688-1695$.

54 Y. Xiong, X. F. He, X. H. Zou, J. Z. Wu, X. M. Chen, L. N. Ji, R. H. Li, J. Y. Zhou and K. B. Yu, Dalton Trans., 2003, 114-119.

55 B. Y. Wu, L. H. Gao, Z. M. Duan and K. Z. Wang, J. Inorg. Biochem., 2005, 99, 1685-1691.

56 A. Rodger and B. Norden, Circular Dichroism and Linear Dichroism, Oxford University Press, New York, 1997.

57 M. F. Ottaviani, F. Furini, A. Casini, N. J Turro, S. Jockusch, D. A Tomalia and L. Messori, Macromolecules, 2000, 33, 7842-7851. 
58 A. K. Patra, M. Nethaji and A. R. Chakravarty, J. Inorg. Biochem., 2007, 101, 233-244.

59 J. Prousek, Pure Appl. Chem., 2007, 79, 2325-2338.

60 S. Wu, W. Yuan, H. Wang, Q. Zhang, M. Liu and K. Yu, J. Inorg. Biochem., 2008, 102, 2026-2034.

61 J. R. Lakowicz, Fluorescence Quenching: Theory and Applications: Principles of Fluorescence Spectroscopy, Kluwer Academic/Plenum Publishers, New York, 1999, pp 53-127.

62 X. Z. Feng, Z. Yang, L. J. Wang and C. Bai, Talanta, 1998, 47, $1223-$ 1229.

63 J. N. Miller, Proc. Anal. Div. Chem. Soc., 1979, 16, 203-208.

64 J. H. Tang, F. Luan and X. G. Chen, Bioorg. Med. Chem., 2006, 14, $3210-3217$

65 P. Krishnamoorthy, P. Sathyadevi, A. H. Cowley, R. R. Butorac and N. Dharmaraj, Eur. J. Med. Chem., 2011, 46, 3376-3387.
66 Y. Li, Z. Y. Yang and M. F. Wang, Eur. J. Med. Chem., 2009, 44, 45854595.

67 T. R. Li, Z. Y. Yang, B. D. Wang and D. D. Qin, Eur. J. Med. Chem., 2008, 43, 1688-1695.

68 Q. Wang, Z. Y. Yang, G. F. Qi and D. D. Qin, Eur. J. Med. Chem., 2009, 44, 2425-2433.

69 P. Sathyadevi, P. Krishnamoorthy, E. Jayanthi, R. R. Butorac, A H. Cowley and N. Dharmaraj, Inorg. Chim. Acta, 2011, DOI: 10.1016/j. ica.2011.11.033.

70 Yun-Jun Liu, Cheng-Hui Zeng, Fu-Hai Wu, Jun-Hua Yao, Li-Xin He and Hong-Liang Huang, J. Mol. Struct., 2009, 932, 105-111.

71 Q. Jiang, J. Zhu, Y. Zhang, N. Xiao and Z. Guo, BioMetals, 2008, 22, 297-305.

72 Zeng-Chen Liu, Bao-Dui Wang, Bo Li, Qin Wang, Zheng-Yin Yang, Tian-Rong Li and Yong Li, Eur. J. Med. Chem., 2010, 45, 5353-5361. 